\title{
SELEÇÃO DE FUNGOS CAUSADORES DE PODRIDÃO BRANCA PARA A BIOPOLPAÇÃO
}

\author{
SÔNIA MARIA PRADO GUILMO \\ Engenheira Florestal
}

orientadora: Profa Dra. Aline A. Pizzirani-Kleiner

Dissertação apresentada à Escola Superior de Agricultura "Luiz de Queiroz", da Universidade de São Paulo, para obtenção do título de Mestre em Agronomia, Área de Concentração: Microbiologia Agrícola.

\footnotetext{
P I RACI CABA

Estado de São Paulo - Brasil

Outubro - 1994
} 
Ficha cataiografica preparada pela Seçào de Livros da Divisac de Eiblioteca E Dacumentaça - FCLQ/USF

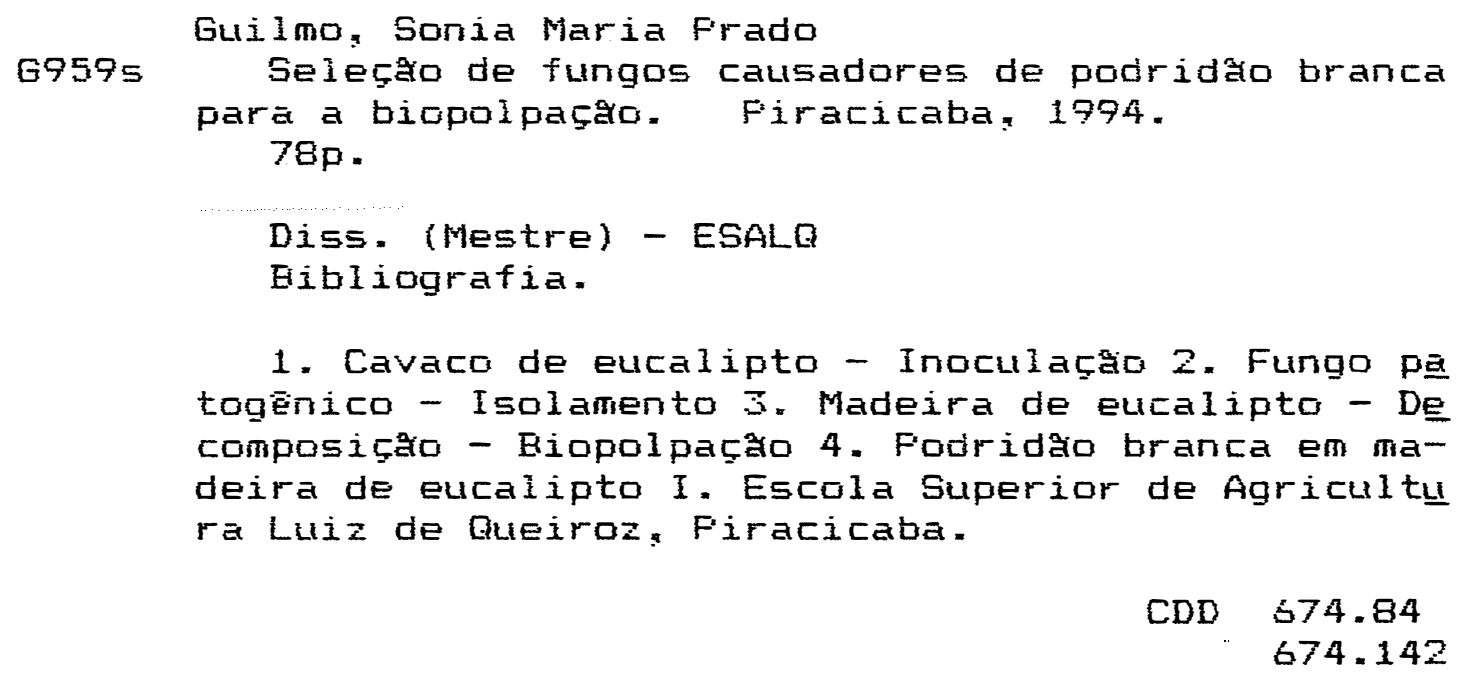

CDD $\quad 574.84$

674.142 


\section{SELEÇÃO DE FUNGOS CAUSADORES DE PODRIDÃO BRANCA PARA A BIOPOLPAÇĀO}

SÔNIA MARIA PRADO GUILMO

Aprovada em: $30 / 11 / 94$

Comissão julgadora:

Profa Dr. Aline Aparecida Pizzirani-Kleiner

ESALQ/USP

Prof. Dr. Luiz Ernesto George Barrichelo

ESALQ/USP

Prof. Dr. Celso Garcia Auer

CNPF / EMBRAPA

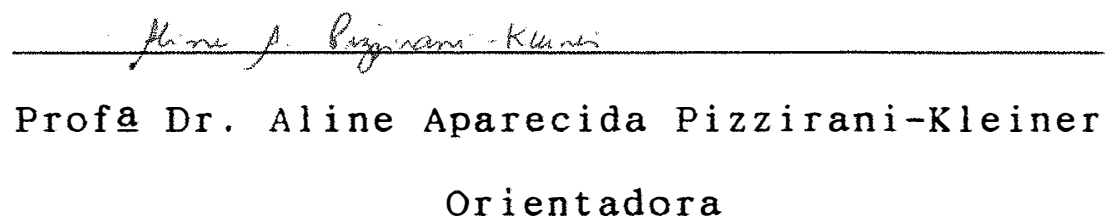


Eternamente agradecida a Deus, dedico aos entes queridos:

meus Pais, meus Irmãos, meu Esposo Adelmo e minha Filha Juliana. 


\section{AGRADEC IMENTOS}

A Escola Superior de Agricultura "Luiz de Queiroz", por intermédio dos Departamentos de Ciência e Tecnologia Agroindustrial e Genética, pela oportunidade.

A Profa Dra Aline A. Pizzirani-Kleiner por sua orientação e confiança que contribuiram para elaboração deste traba1 ho.

Ao Dr. Celso Garcia Auer, pelas sugestões, incentivo e ami zade.

Ao Prof. Dr. Luiz Ernesto George Barrichelo pelo apoio, estímulo e confiança.

Ao Dr. Eduardo L. Vianna Dória, pela contribuição e pelas sugetões durante a realização deste trabalho.

A Empresa ARACRUz Celulose S/A, por intermédio do Centro de Tecnologia, pelo apoio e auxílio na parte experimental do trabal ho. 
Aos funcionários do Centro de Tecnologia da Empresa ARACRUZ CELULOSE S/A, especialmente ao supervisor Gerson Gonçalves dos Santos pela contribuição e atenção.

A técnica Maria Regina Bush e aos estagiários do Setor de Química, Celulose e Energia pela colaboração recebida nas diversas fases do trabalho.

A Fundação de Amparo à Pesquisa do Estado de São Paulo, pela concessão da Bolsa de Estudos.

Aos Departamentos de Genética e Ciência e Tecnologia Agroindustrial pela agradável convivência.

Ao Prof. Tasso Leo Krugner pelo auxílio na identificação dos fungos, durante aula prática da disciplina Micologia.

Aos professores Luiz Gonzaga Prado Filho e Antonio Joaquim de Oliveira, pelas inúmeras sugestões apresentadas.

A todos os que de alguma forma colaboraram para a realização deste trabalho. 


\section{SUMÁR IO}

Página

LISTA DE FIGURAS $\ldots \ldots \ldots \ldots \ldots \ldots \ldots \ldots \ldots \ldots \ldots \ldots \ldots \ldots \ldots \ldots \ldots \ldots \ldots$

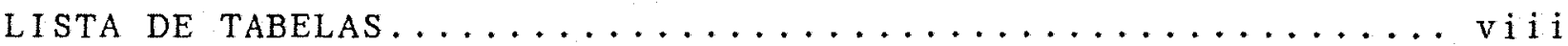

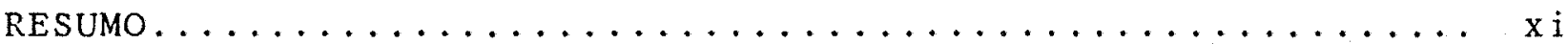

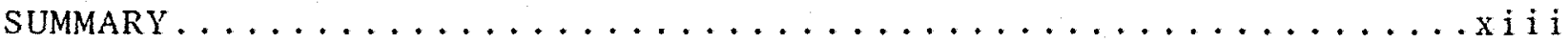

1. INTRODUÇÃO $\ldots \ldots \ldots \ldots \ldots \ldots \ldots \ldots \ldots \ldots \ldots \ldots \ldots \ldots \ldots$

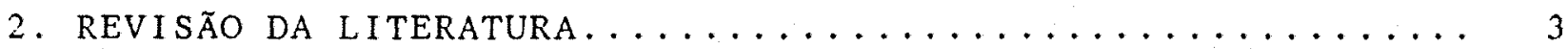

2.1. A Madeira e Sua Decomposição Biológica........... 3

2.2. A Celulose da Madeira e Sua Degradação............ 6

2.3. A Hemicelulose e Sua Biodegradação............. 10

2.4. A Lignina da Madeira e Sua Degradação............ 12

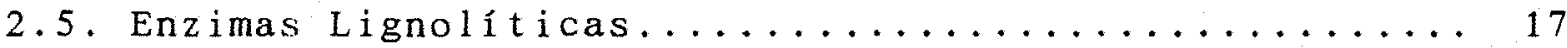

2.6. Métodos de Determinação de Lignina.............. 19

2.7. Potenciais para a Indústria e o Processso de

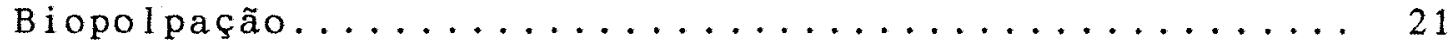

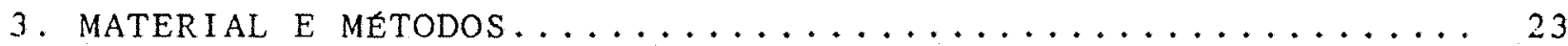

3.1. Montagem da Pilha de Cavacos e Coleta de Amostras... 23

3.2. Determinação do Teor de Umidade............... 24

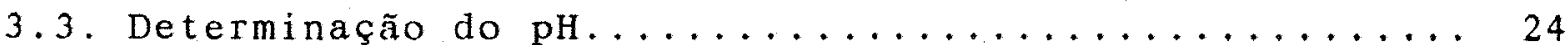

3.4. Isolamento e Identificação dos Fungos........... 25

3.5. Análises Químicas dos Cavacos Armazenados......... 27

3.5.1. Determinação de Extrativos da Madeira...... 27

3.5.1.1. Extrativos Totais........... 27

3.5.1.2. Extrativos Solúveis em $\AA 1$ cool-

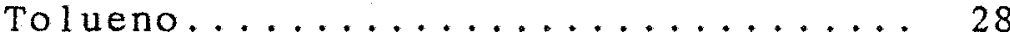

3.5.1.3. Extrativos em Diclorometano....... 29

3.5.2. Determinação do Teor de Lignina........... 29 
3.5.3. Determinação do Teor de Holocelulose....... 30

3.6. Seleção de Fungos Lignolíticos ............... 31

3.7. Avaliação da Atividade Lignolítica............... 32

3.7 .1 . Obtenção do Substrato de Lignina.......... 32

3.7 .2 . Inóculo e cultivo.................. 32

3.7.2.1. Meio Utilizado Para o Cultivo dos

Fungos em Estudo.............. 33

3.7.3. Quantificação da Degradação da Lignina....... 35

3.8. Pré-Tratamento Biológico dos Cavacos........... 35

3.8 .1 . Microrganismos Utilizados.............. 35

3.8 .2 . Madeira Utilizada................ 36

3.8 .3 . Inoculação dos Cavacos............... 36

3.9. Avaliação do Pré-Tratamento Biológico........... 38

3.9.1. Análises Químicas dos Cavacos Tratados...... 38

3.9 .2 . Densidade Básica.................. 38

3.10. Cozimentos Experimentais................. 40

3.11. Análise Estatística................... 42

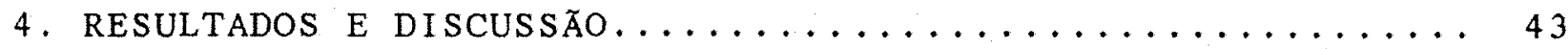

4.1. Monitoramento da Pilha de Cavacos............. 43

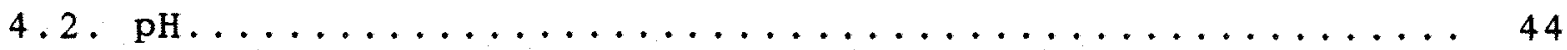

4.3. Isolamento e Identificação dos Fungos............ 46

4.4. Determinação dos Extrativos de Madeira........... 50

4.5. Determinação dos Teores de Lignina e Holocelulose... 56

4.6. Seleção dos Fungos Lignolíticos.............. 60

4.6.1. Determinação da Atividade Lignolítica........ 60

4.7. Pré-Tratamento Biológico dos Cavacos............ 65

4.7 .1 . Teste de Eficiência de Inoculação.......... 65

4.7 .2 . Densidade Básica.................. 67 
vi .

4.8. Análises Químicas...................... 67

4.8.1. Características da Polpa Não Branqueada...... 68

5. CONCLUSÕES ................................ 71

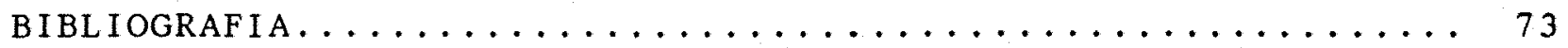




\section{ISTA DE FIGURAS}

Página

Figura 1 . Estrutura da Celulose.................. 7

Figura 2. Esquema de Decomposição da Celulose Cristalina... 8

Figura 3. Carboidratos simples que compõem as hemiceluloses. 11

Figura 4. Atividade lignolítica do fungo Botryosphaeria de cavacos com podridão branca, comparado com o fungo

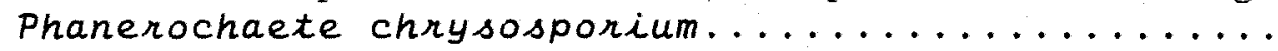

Figura 5. Atividade lignolítica do fungo Fusarium de cavacos com podridão branca, comparado com o fungo

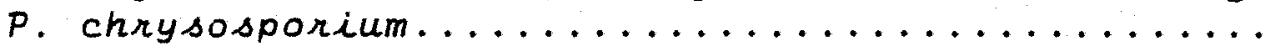

Figura 6. Atividade lignolítica do fungo sporotrichum de cavacos com podridão branca, comparado com o fungo

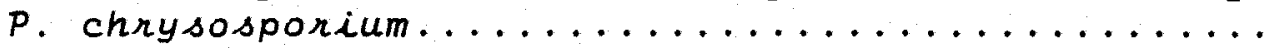

Figura 7. Atividade lignolítica do fungo Basidiomiceto de cavacos com podridão branca, comparado com o

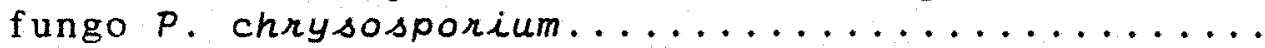

Figura 8. Atividade lignolítica do fungo Basidiomiceto (2) de cavacos com podridão branca, comparado com o

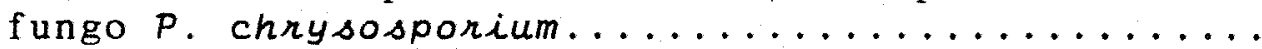

Figura 9. Atividade lignolítica do fungo Basidiomiceto (3) de cavacos com podridão branca, comparado com o

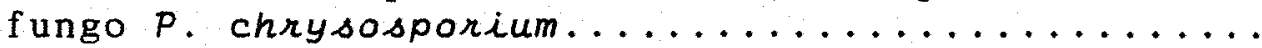




\section{LISTA DE TABELAS}

Página

Tabela 1. Atividades das enzimas implicadas na degradação

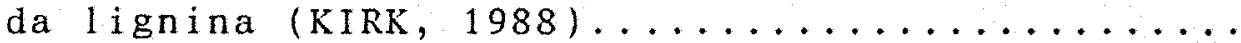

Tabela 2. Valores médios de umidade dos cavacos (\%) coletados em quatro pontos externos da pilha de cavacos de Eucalyptus grandis, durante o armazenamen-

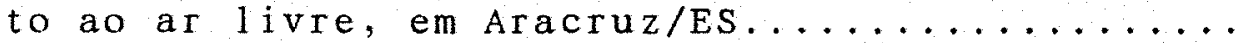

Tabela 3. Valotes médios de pH dos cavacos coletados em quatro pontos externos da pilha de cavacos de E. grandis, durante 0 armazenamento ao ar livre,

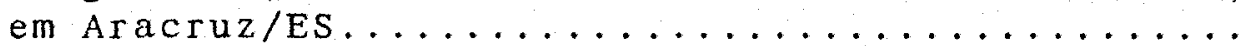

Tabela 4. Incidência (\%) de fungos isolados de cavacos de $E$. grandis recém-picados, sob dois métodos de isolamento e incubação em meio Martin (MMA) de 72

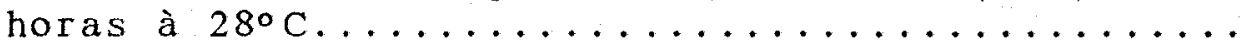

Tabela 5. Freqüencia (\%)* dos fungos em quatro pontos externos da pilha de cavacos de $E$. grandis, com vários períodos de armazenamento, isolados de cavacos não flambados e incubação em MMA por 72 horas

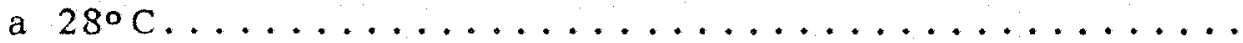

Tabela 6. Freqüência $(\%)^{*}$ dos fungos em quatro pontos externos da pilha de cavacos de E. grandis, com vários períodos de armazenamento, isolados de cavacos flambados e incubação em MMA por 72 horas a

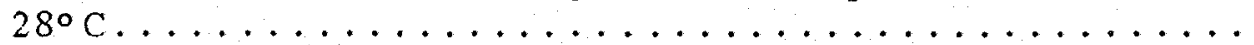

Tabela 7. Valores médios* do teor de extrativos totais (\%) de cavacos coletados em quatro pontos externos da pilha de cavacos de E. grandis, durante o armazenamento ao ar livre, em Aracruz/ES............

Tabela 8. Análise de variância dos valores médios do teor de extrativos totais $(\%)$, nos diferentes periodos

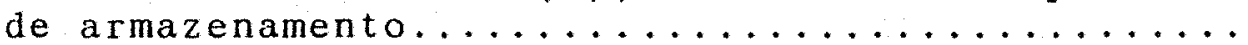

Tabela 9. Teste Tukey para médias dos valores de extrativos totais $(\%)$, nos diferentes períodos de armazena-

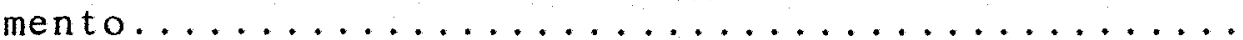

Tabela 10. Valores médios* do teor de extrativos solúveis em diclorometano (\%) de cavacos coletados em quatro pontos externos da pillha de cavacos de $E$. grandis, durante o armazenamento ao ar livre, em

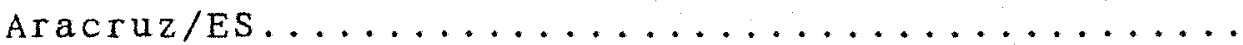


Tabela 11. Análise de variância dos valores médios do teor de extrativos solúveis em diclorometano (\%), nos diferentes períodos de armazenamento..........

Tabela 12. Teste Tukey para médias dos valores de extrativos solúveis em diclorometano (\%), nos diferentes pe-

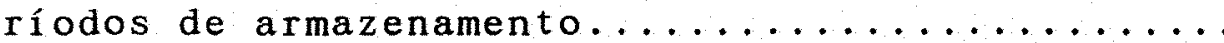

Tabela 13, Valores médios* do teor de extrativos solúveis em álcool-tolueno $(1: 2)(\%)$ de cavacos coletados em quatro pontos externos da pilha de cavacos de E. grandis, durante o armazenamento ao ar livre,

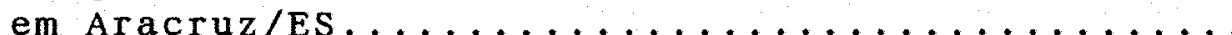

Tabela 14. Análise de variância dos valores médios do teor de extrativos solúveis em álcool-tolueno (\%), nos diferentes períodos de armazenamento...........

Tabela 15. Teste Tukey para médias dos valores de extrativos solúveis em álcool-tolueno (\%), nos diferentes períodos de armazenamento.................

Tabela 16. Valores médios do teor de lignina (\%) de cavacos coletados em quatro pontos externos da pilha de cavacos de $E$. grandis, durante o armazenamento ao

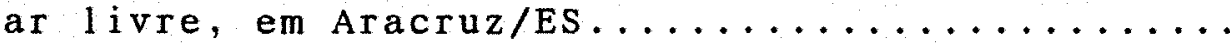

Tabela 17. Análise de variância dos valores médios do teor de lignina (\%), nos diferentes períodos de arma-

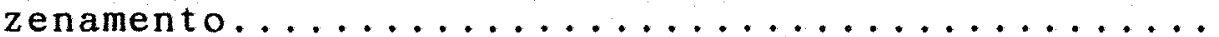

Tabela 18. Teste Tukey para médias dos valores de teor de lignina nos diferentes períodos de armazenamento.

Tabela 19. Valores médios* do teor de holocelulose (\%) de cavacos coletados em quatro pontos externos da pilha de cavacos de $E$. grandis, durante o armazenamento ao ar livre, em Aracruz/ES............

Tabela 20. Análise de variância dos valores médios do teor holocelulose (\%), nos diferentes períodos de ar-

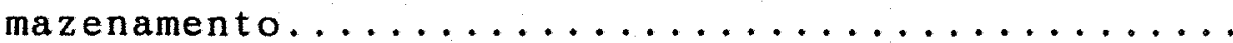


Tabela 21. Teste Tukey para médias dos valores de teor de holocelulose nos diferentes períodos de armazena-

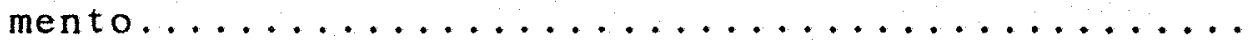

Tabela 22. Atividade lignolítica dos fungos isolados, compa-

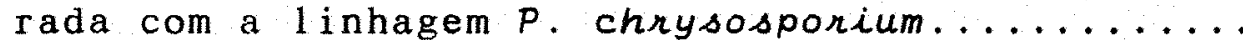

Tabela 23. Reisolamento dos fungos nos cavacos.......... 66

Tabela 24. Densidade básica de cavacos de madeira de E. grandis após vários tratamentos............

Tabela 25. Composição química (\%) dos cavacos de madeira de

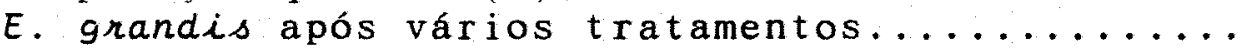

Tabela 26. Rendimento bruto (RB), rendimento (RD), teor de rejeitos (RE), em porcentagens, e número Kappa de celuloses não branqueadas de $E$. grandis......... 


\title{
SELEÇÃO DE FUNGOS CAUSADORES DE PODRIDÃO BRANCA PARA A BIOPOLPAÇÃO
}

\author{
Autora : Sônia Maria Prado Guimo \\ Orientadora: Profa Dra. Aline A. Pizzirani-Kleiner
}

\section{RESUMO}

O isolamento de fungos decompositores a partir de cavacos de Eucalyptus grandis mostrou a ocorrência de Aspergillus sp., Penicillium sp., Sporotrichum sp., Rhizomucor sp., Botryosphaeria sp., Fusarium sp., Trichoderma sp., Eurotium sp. e três fungos da classe dos Basidiomicetos de gêneros não identificados.

Foram avaliadas as freqüências relativas de cada fungo isolado observando-se a sucessão de microrganismo no decorrer do período de armazenamento.

Os fungos isolados foram selecionados pela capacidade de degradação da lignina em meio de cultivo, por meio da análise espectrofotométrica da lignina residual, e comparados ao fungo ligninolítico Phanerochaeta chrysosporium. Entre os isolados foram selecionados os três Basidiomicetos de gêneros não identificados e o fungo Fusarium sp.

Cavacos de $E$. grandis foram inoculados com os fungos visando determinar sua potencialidade para redução do consumo de 
xi i.

reagentes químicos durante o cozimento e incrementar o rendimento em celulose depurada do cozimento.

A celulose obtida de cavacos não tratados com os fungos selecionados apresentou maior número Kappa, maior porcentagem de rejeitos, quando comparada com a celulose de cavacos tratados biologicamente.

Os fungos selecionados mostraram-se eficientes, com potencial para redução de reagentes químicos no processo de polpação e no incremento do rendimento depurado do processo. 
xi i i .

\title{
THE SELECTION OF FUNG I WHICH CAUSES WHITE ROT TO THE B IOPULP ING
}

\author{
Author : Sônia Maria Prado Guimo \\ Adviser: Profa Dra. Aline A. Pizzirani-Kleiner
}

\section{SUMMARY}

The isolation of fungi decompositors from chips of Eucalyptus grandis, showed the occurence of Aspergillus sp., Penicillium sp., Sporotrichum sp., Rhizomucor sp., Botryosphaeria sp., Fusarium sp., Trichoderma sp., Eurotium sp. and three fungi belonging to the class of the Basidiomycetes of the nonident if ied kind.

The relative frequencies of each isolated fungus have been evaluated by observing the sequence of the microrganism during the period of storage.

The isolated fungi were selected by the capacity of deterioration of the lignin in the midth of cultivation, by means of the spectophotometric analysis of the residual lignin, and compared to the ligninolitic fungus Phanerochaete chrysosporium. Among the isolated ones were selected the three basidiomycetes and Fusarium sp. kind.

Chips of wood from Eucalyptus grandis were inoculated with the fungi with the purpose of determining its potentiality 
xiv.

for the reduction of consumption of chemical reagents during the cooking in order to develop the yield of pulp depurated of cooking.

The cellulose of chips which were not treated with the selected fungi showed a higher number of Kappa, a higher porcentage of rejections, when compared to the cellulose of chips biologically treated.

The selected fungi appeared to be efficient, with the power of reducing the chemical reagents in the pulping process and in the developness of the depurated revenue of the process. 


\section{I . INTRODUÇÃO}

o gênero Eucalyptus é a principal matéria-prima de fibras curtas para produção de celulose e chapas no Brasil, principalmente no estado de São paulo, onde a maior parte das indústrias mantém plantações de Eucalyptus visando a sua auto suficiência (SIMÕES et alii, 1980). No estágio atual, a produção de polpa celulósica fundamenta-se basicamente no processo kraft ou sulfato, tendo como agentes ativos de cozimento da madeira o hidróxido e o sulfeto de sódio. O objetivo desse proceso, bem como dos outros processos químicos de produção de polpa celulósica, é facilitar a separação das fibras pela dissolução da lignina. As razões que contribuíram para enorme aceitação do processo kraft foram: pouca sensibilidade às variações nas condições da madeira, curtos ciclos de cozimento, polpa com alta resistência físico-mecânica e recuperação econômica do licor de cozimento. Entretanto, o processo apresenta algumas desvantagens, tais como: baixo rendimento, polpa muito escura que demanda elevada aplicação de reagentes químicos no processo de branqueamento e grande potencial de poluição.

A indústria de celulose com elevada concentração de uso de energia química e mecânica utiliza um insumo altamente biode- 
gradável como matéria-prima. Associado a este fato, a estocagem de madeira na forma de cavacos ao ar livre proporciona condições ideais para maior atividade de agentes deterioradores de madeira.

Em razão da existência de microrganismos capazes de degradar a madeira, ocasionando uma parcial deslignificação da mesma, surge o chamado processo de biopolpação (KIRK et alii, 1983). O pré tratamento biológico dos cavacos com fungos lignolíticos tem se mostrado eficiente, tanto na redução do consumo de reagentes quimicos quanto do incremento das propriedades físicomecânicas da polpa.

$\mathrm{Na}$ natureza grande diversidade de microrganismos podem degradar lignina; entretanto, os fungos causadores da podridão branca são os mais eficientes nesse processo. Entre eles o mais estudado é o fungo Phanerochaete chrysosporium, pois possui um sistema enzimático capaz de degradar todas as formas de lignina, até gás carbônico e componentes solúveis em água.

o presente trabalho teve por objetivos:

- isolar fungos decompositores de madeira de $E$. grandis em processo natural de decomposição;

- determinar a capacidade degradativa de isolados sobre a lignina da madeira desta espécie; e

- estudar o efeito de alguns fungos selecionados sobre a madeira colonizada e utilizada no cozimento dos cavacos, para verificar o rendimento de celulose produzida e grau de deslignificação. 


\section{2 . REVISÃO DA LITERATURA}

\subsection{A Madeira e Sua Decomposição Biológica}

A madeira é composto primordialmente de celulose, hemicelulose e lignina. Estes polímeros formam a parede celular da madeira e são responsáveis pela maioria das suas propriedades físicas e quimicas. De forma simplificada pode se dizer que a celulose forma um esqueleto imerso numa matriz de hemicelulose e lignina, que é o material aglutinante (LEPAGE, 1986).

Além da celulose, lignina e hemicelulose, que são os componentes majoritários, todas as madeiras contêm pequenas quantidades de outros componentes que não fazem parte da estrutura da parede celular, mas que estão provavelmente presentes, pelo menos em parte, como conteúdo da célula. Esses componentes, designados pelo nome genérico de extrativos são bastante variados quanto à natureza química, englobando diferentes compostos orgânicos, como por exemplo, taninos, resinas, óleos essenciais, gorduras, terpenos, flavonóides, quinonas, carboidratos e alcalóides (LEPAGE, 
1986). O mesmo autor cita que todas as madeiras possuem também pequenas quantidades $(0,2 \%)$ de compostos nitrogenados, provavelmente proteínas. Isso pode ser importante nos processos de ataque da madeira por microrganismos e insetos xilófagos, que necessitam de nitrogênio para seu metabolismo. Segundo DICKINSON (1974), os altos teores de materiais 1 ignocelulósicos es teores muito baixos de nitrogênio têm um efeito negativo no crescimento e na atividade degradadora dos microrganismos nos tecidos lenhosos. Entretanto, o autor afirma que um grande número de organismos atuando simultaneamente e/ou em sucessão são capazes de decompor madeira sob condições externas favoráveis em um tempo relativamente pequeno, sendo os Basidiomicetos considerados como principais agentes da degradação.

Diferentes tipos de organismos estão envolvidos no processo que resulta na decomposição da madeira. A primeira infestação depende da presença de organismos pioneiros e da condição de exposição inicial da madeira. Durante a degradação, o substrato modifica-se continuamente $e$ isso, junto com a interação dos organismos entre si, resulta em sucessivas trocas nas populaçōes de microrganismos decompositores da madeira (DICKINSON, 1974 e DIEHM, 1977). Segundo DIEHM (1977), dado que a celulose, as hemiceluloses e a lignina são os principais constituintes da madeira, é de suma importância a facilidade com que os quais são atacados pelos diversos microrganismos. O autor afirma, ainda, que os fungos parasitas e saprófitos são muito ativos na decomposição da madeira, podendo crescer sobre a mesma com teores de umidade acima de $20 \%$. Esta umidade pode ser encontrada na madeira verde 
ou parcialmente seca. Posto que as bactérias necessitam uma umidade muito maior que essa, elas raramente iniciam a decomposição da madeira sob condições normais de armazenamento. Elas se limitam a crescer em lugares onde os fungos iniciaram o processo de degradação, uma vez que a madeira decomposta absorve e retém uma quantidade maior de umidade.

KAARIK (1975) classificou os microrganismos xilofagos com base em suas atividades enzimáticas nos seguintes grupos:

- Microrganismos que se utilizam das substancias existentes no lúmen das células de madeira e que não decompõem, enzimaticamente, as paredes celulares: fungos manchadores e bolores.

- Microrganismos capazes de promover a degradação enzimática das paredes celulares:

* Microrganismos com capacidade limitada de degradação: bactérias e fungos de podridão mole.

* Fungos apodrecedores, geralmente com alta capacidade de degradação: fungos de podridão parda e de podridão branca.

Com desenvolvimento das bactérias, bolores primários e fungos manchadores, ocorre gradativa diminuição na quantidade de açúcares simples facilmente metabolizáveis. Após o esgotamento destes compostos, o número de colonizadores pioneiros cai e chega a vez de microrganismos especializados. Surge então, a dominância dos fungos de podridão mole. Estes são Ascomicetos e Deuteromicetos, cujas hifas desenvolvem-se dentro das paredes celulares e 
que decompõem, fundamentalmente, a celulose e hemiceluloses. E interessante aqui ressaltar que muitas espécies de fungos, tidos, em princípio, apenas como bolores ou manchadores mostram-se capazes de provocar podridão mole em estágios avançados de ataque à madeira. Este fato sugere que, em muitos casos, a distinção entre fungos emboloradores, manchadores e de podridão mole reflete muito mais a exploração de diferentes nichos ecológicos (devido à mudança no estágio nutricional ou substrato) por um grupo relativamente amplo e homogêneo de espécies, do que a ocorrência de grupos taxonômicos distintos (KAARIK, 1974; KAARIK, 1975 ; LEVY \& DICKINSON, 1981; SCHEFFER, 1973).

Finalmente, o clímax da sucessão ocorre quando a população de fungos de podridão mole declina e é substituída por Basidiomicetos. Estes colonizam profundamente a madeira de decompõem os tecidos lenhosos numa velocidade normalmente bastante alta. Os Basidiomicetos capazes de decompor a madeira são divididos em dois tipos: fungos de podridão parda e fungos de podridão branca. Os primeiros decompõem apenas os polissacarídeos da parede celular e os últimos, tanto os polissacarídeos quanto a lignina. Em ambos os casos, a hifas desenvolvem-se no lúmen das células (LEPAGE, 1986).

2.2. A Celulose da Madeira e Sua Degradação

A celulose é o principal constituinte da parede celular da maioria das plantas, é um polímero formado por unidades do monossacarídeo $\beta-D-g l u c o s e$, que se ligam entre si através dos 
carbonos 1 e 4 , dando origem a um polímero linear (FENGEL \& WEGENER, 1984). Na natureza, a celulose está organizada em fibrilas, que consistem de diversas moléculas de celulose arranjadas de forma paralela e ligadas por pontes de hidrogenio (VICENTE, 1989). A análise por raios $X$ mostrou que as fibras são constituídas de regiões cristalinas (altamente ordenadas) e amorfas (desordenadas) (SJOSTRÖM, 1981). A estrutura da celulose está apresentada na Figura 1.

\section{CELULOSE}

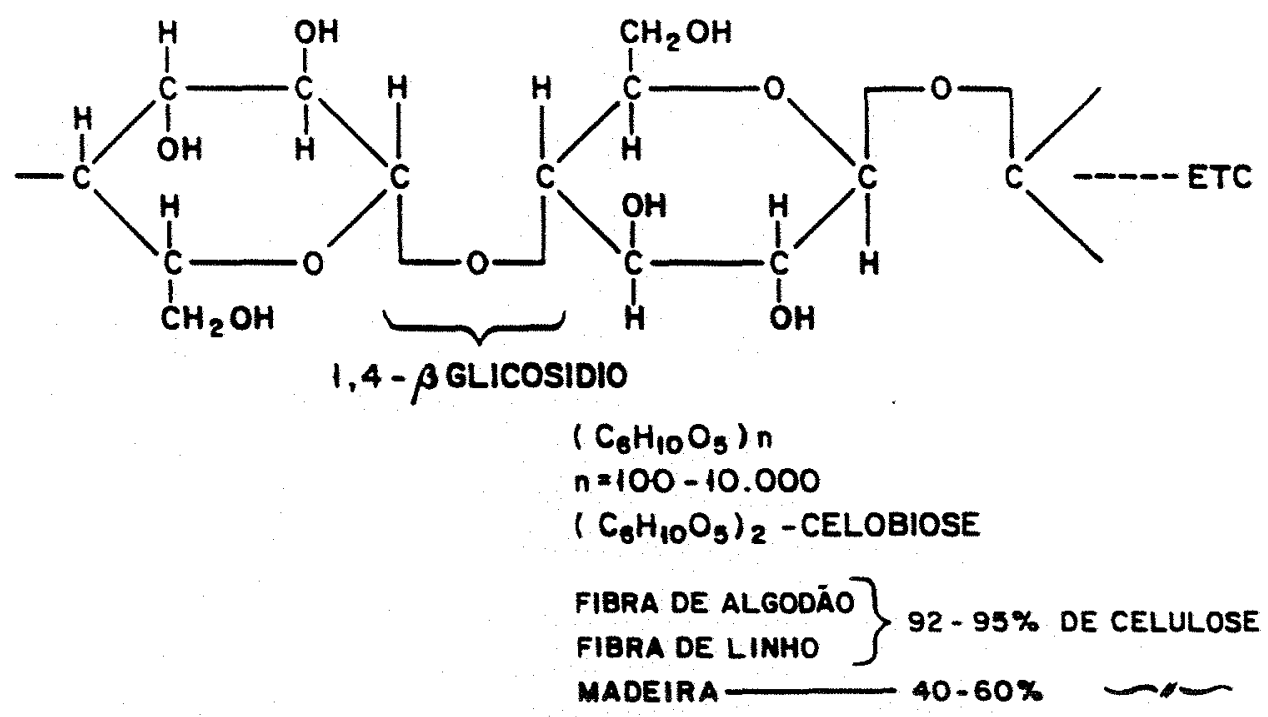

Figura 1. Estrutura da Celulose Fonte : DROZDOWICZ (1991)

A degradação biológica da celulose consiste em uma hidrólise enzimática catalisada pela celulase, que é uma enzima produzida amplamente por fungos e bactérias (LIMA et alii, 1988). Entretanto, entre os microrganismos produtores de celulases, os fungos tem despertado maior interesse pois geralmente suas enzimas são excretadas no meio de cultura, enquanto que nas bactérias estão ligadas à parede celular. As diferenças na distribuição das 
ses implicam em várias maneiras de decomposição da celulose. Para utilizar a matéria celulósica as bactérias devem aderir à fibra da celulose, enquanto os fungos podem aproveitar também a celulose distante de suas hifas (wOOD, 1985).

REESE, et alii (1950) desenvolveram um esquema no qual ele diferencia dois hipotéticos fatores $C_{1}$ e $C_{x}$. O componente $C_{1}$ seria enzimas de caráter não-hidrolítico, responsável pela separação das cadeias da celulose cristalina. A celulose modificada seria então hidrolisada pelo componente $C_{x}$ e pela $\beta-g l i c o s i d a s e$. O esquema da decomposição da celulose por microrganismos celulolíticos legítimos, sugeridos por REESE, está apresentado na Figura 2 .
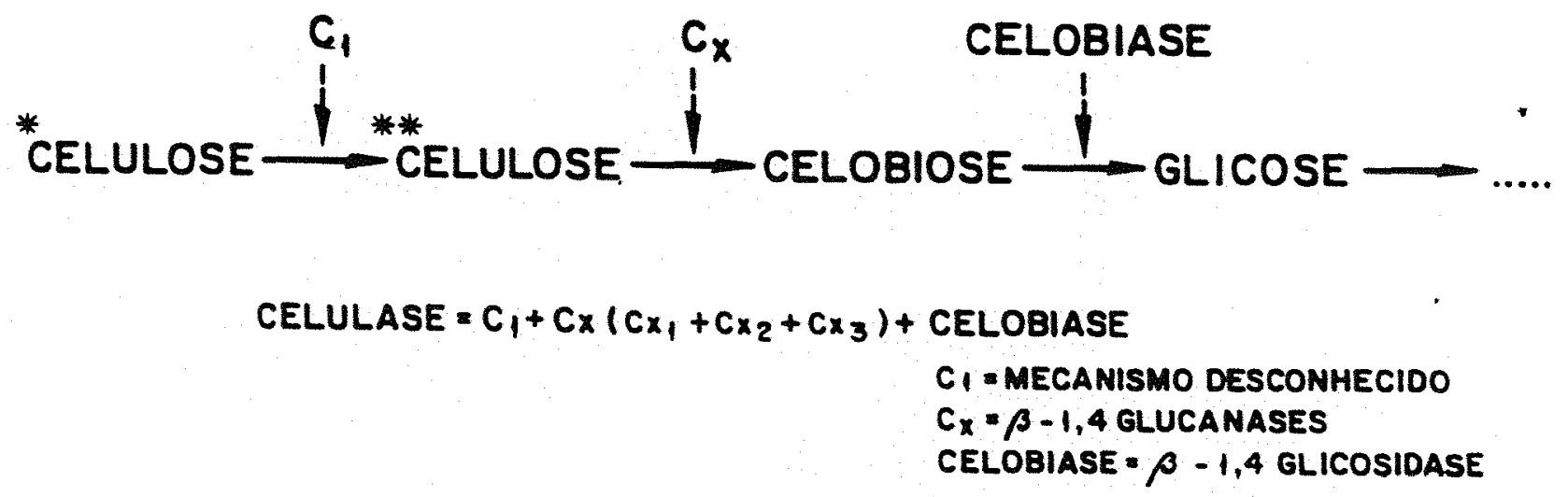

* Cristolino, resistente

* * Reativa

Figura 2. Esquema de Decomposição da Celulose Cristalina. O fator $\mathrm{C}_{1}$ modifica a estrutura da celulose transformando-a em forma degradável. As $\beta-1,4$ glucanases que compõe a celulase $\left(C_{x}\right)$ hidrolisam sucessivamente a molécula de celulose até o dímero celobiose.

Fonte: DROZDOWICZ (1991) 
A ação sinérgica dos fatores $C_{1}$ e das $\beta-1,4-g l u c a n a s e s$ que compõe a fração $C_{x}$ torna os açúcares solúveis capazes de penetrar nas células dos organismos celulolíticos e aí serem incluídos no metabolismo celular. Um dos primeiros e principais açúcares solúveis é a celobiose, hidrolizada em seguida pela 1,4$\beta-D-g l u c o s i d a d e$ (celobiose-hidrolase) em duas moléculas de glucose (DROZDOWICS, 1991).

As enzimas do complexo celulolítico são sintetizados por fungos, actinomicetos e bactérias. Entre os fungos, os gêneros mais estudados são Trichoderma, sporotrichum, Penicileium, Fusarium, Aspergillus, pleurotus. Em geral os microrganismos não produzem todas as enzimas do complexo celulolítico em proporções iguais. Assim o gênero Trichoderma, em especial o $T$. reesei considerada o melhor produtor de celulases extracelulares, é um bom produtor de exo e endocelulases, porém produz pouca $\beta-g l i c o s i d a-$ de; em compensação esta última é produzida em abundante quantidade por algumas espécies de Penicillium (FUnAGUMA et alii, 1986; ROUMAS, 1988$)$.

$\mathrm{Na}$ natureza, os microrganismos celulolíticos legítimos iniciam provavelmente a colonização da celulose nativa presente em detritos vegetais transformando-a em celulose reativa. Em seguida, a decomposição total ocorre com a participação de vários grupos de microrganismos que dispõem do conjunto $C_{x}$

A regulação celulolítica é semelhante aos sistemas indutíveis já conhecidos. O indutor liga-se ao repressor dentro da célula, ativando a síntese enzimática. A celulase extracelular 
é produzida pelos organismos em resposta à presença de certos substratos no meio de crescimento. Entre os indutores da síntese de celulase incluem-se celulose, derivados da celulose, celobiose, soforose e lactose (VICENTE, 1989).

De acordo com a teoria proposta por MANDELS \& REESE (1960), as celulases constitutivas dão origem e produtos solúveis oriundos da hidrólise da celulose, que entram nas células dos microrganismos e funcionam como indutor.

\subsection{A Hemicelulose e Sua Biodegradação}

As hemiceluloses referem-se a uma mistura de polissacarídeos de baixa massa molecular, os quais estão intimamente associados com a celulose nos tecidos das plantas (SJÖSTRÖM, 1981 ). Enquanto a celulose, como substância química, contém exclusivamente a D-glucose como unidade fundamental, as hemiceluloses são polímeros, em cuja composição podem aparecer, condensados em porções variadas, as seguintes unidades de açúcar: $\beta-D-x i l o s e, \beta-$ D-manose, $\beta-D-g l u c o s e, \quad \alpha-L-a r a b i n o s e, \quad \alpha-D-g a l a c t o s e$, ácido $\beta-D-$

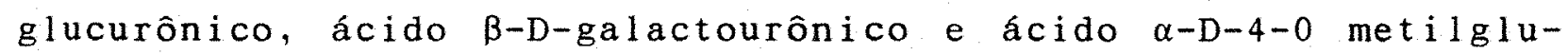
curônico (ALMEIDA, 1988). Os açúcares que compõem as hemiceluloses estão apresentados na Figura 3 . 

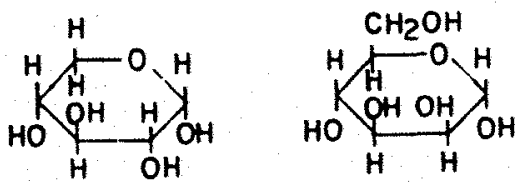

- D-XILOSE

- o-manose

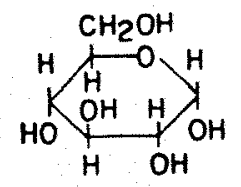

P. -D-GLucose
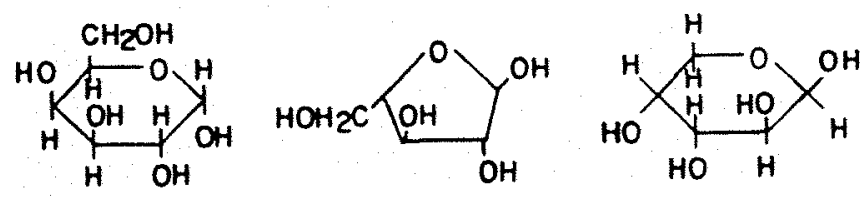

L-D-gALACTOSE

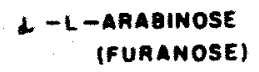

$\perp$-L -ARABINOSE
(PIRANOSE)
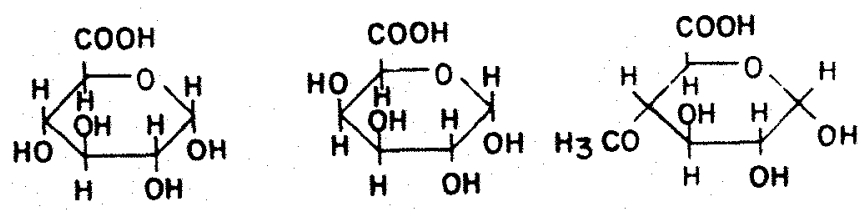

ÁCIDO -D-GALACTOURÔMICO

Ácioo B-D-GUCCUAÓnico ÁCIDO L-D-4-O-METILGLUCOURÖNICO

Figura 3. Carbohidratos simples que compõem as hemiceluloses. Fonte: ALMEIDA (1988).

As hemiceluloses são polímeros, nas quais participam pelo menos dois tipos de unidades de açúcar. Assim, as hemiceluloses isoladas das madeiras são misturas complexas de polissacarídeos, sendo os mais importantes: glucuranoxilanas, arabinoglucuranoxilanas, glucomananas, arabinogalaclanas e galactoglucomananas (FENGEL \& WEGENER, 1984 ).

O termo hemiceluloses não designa um composto químico definido, mas sim uma classe de compostos poliméricos, possuindo cada componente propriedades peculiares. Como no caso da celulose e da lignina, o teor e a proporção dos diferentes componentes encontrados nas hemiceluloses de madeira variam grandemente com a 
espécie e, provavelmente, também de árvore para árvore (ALMEIDA, $1988)$.

o mecanismo bioquímico de decomposição das hemiceluloses é, em termos genéricos, bastante semelhante àquele da celulose, no seu aspecto hidrolítico. Entretanto, para hidrólise das hemiceluloses é necessário um conjunto enzimático mais complexo, uma vez que diferentes tipos de ligações e unidades monoméricas estão presentes na estrutura química das hemiceluloses.

Segundo KIRK (1983), na degradação das hemiceluloses, endo-gliconases atuam sobre as moléculas produzindo dímeros, oligômeros e monômeros, que são posteriormente metabolizados.

Os fungos apodrecedores produzem várias enzimas capazes de decompor diversas glicanas e glicosídeos, sendo que, aparentemente, os mecanismos são similares entre si e não existem diferenças marcantes entre os diferentes microrganismos (HIGHLEY, $1976)$.

Os mecanismos de regulação da síntese de hemicelulases não foram ainda alvo de estudos sistemáticos. Atividade hemicelulolítica múltipla é encontrada em filtrados de culturas de fungos desenvolvidos sobre diversos substratos (KIRK, 1983).

\subsection{A Lignina da Madeira e Sua Degradação}

As ligninas são polímeros tri-dimensionais constituídos de unidades fenilpropano, apresentando composições diferentes 
ra coníferas e folhosas (ROWELL, 1984). Elas incrustam o espaço intercelular e qualquer abertura na parede celular, após a deposição da celulose e das hemiceluloses (FENGEL \& WEGENER, 1984). Perfazem um total de $30 \pm 4 \%$ para as coníferas, $25 \pm 3 \%$ para as folhosas de zona temperada e $29 \pm 4 \%$ para folhosas de zona tropical (BROWNING, 1963).

A lignina pode ser classificada em:

- lignina das gimnospermas ou coníferas: seus produtos de oxidação com nitrobenzeno são, principalmente, vanil ina e para-hidroxibenzaldeído;

- lignina das angiospermas ou folhosas: seus produtos de oxidação com nitrobenzeno são ácido siríngico e vanila.

- lignina das gramíneas: seus produtos de oxidação são ácido siríngico, vanilina e para-hidroxibenzaldeído (SARKANEN \& LUDWIG, 1971).

Outra classificação seria que divide as ligninas em duas classes principais: as ligninas guaiacil e as ligninas guaiacilsiringil. A primeira classe inclui as ligninas presentes na maioria das coníferas e a segunda classe, todas as ligninas de angiospermas (arbóreas e herbáceas, incluindo as gramíneas) (CASEY, $1980)$.

Em tecidos plenamente lignificados (teor de lignina maior ou igual a $20 \%$ ) os mais importantes decompositores são os Basidiomicetos capazes de decompor a lignina. Estima-se em cerca de 1.800 o número dessas espécies de Basidiomicetos, para o hemisfério norte. Nas regiōes tropicais e hemisfério sul, o total deve 
ser bem maior. Em qualquer evento envolvendo a decomposição de materiais lignocelulósicos, é bastante alta a incidência deste grupo de microrganismos, o que revela a sua importância ecológica (KIRK, 1983).

Segundo CRAWFORD (1981) citado por VICENTE (1989), os fungos que causam podridão branca são conhecidos como os maiores decompositores, pois são capazes de degradar todos os componentes incluindo a lignina.

Macroscopicamente, a madeira com podridão branca apresenta-se mais clara que a sadia e mais macia que esta. As vezes, as áreas apodrecidas podem estar delimitadas por linhas escuras. Em outros casos, pequenas áreas apodrecidas encontram-se intermeadas por áreas sadias. Neste caso, o apodrecimento recebe o nome de podridão branca em bolsas (SCHEFFER, 1973). O mesmo autor cita que em estágios iniciais, as hifas destes fungos colonizam extensivamente os raios e vasos (folhosas), penetrando nas fibras e traqueídeos, apenas em estágios posteriores de ataque. A passagem de célula para célula pode ocorrer através da parede graças a enzimas produzidas nos topos e superfícies laterais das hifas, formando perfurações que podem ser ampliadas em estágios avançados de ataque. Nos tecidos lignificados, as hifas permanecem no lúmen da célula e degradam a parede celular de dentro para fora, a partir da camada $S_{3}$ provocando o gradativo afinamento da camada celular.

OTJEN \& BLANCHETTE (1987), através de uma seleção, utilizando-se de microscopia eletrônica, verificou 30 fungos 
responsáveis pela podridão branca, removiam lignina da gimnosperma (Pinus strobus) e da angiosperma (Betula papyrifera).

As pesquisas com fungos de podridão branca têm mostrado que o processo de decomposição da lignina é oxidativo, que a depolimerização não é um passo inicial obrigatório e que o sistema lignolítico não é específico e nem é induzido pela lignina. As principais relações na degradação da lignina são oxidações e clivagens oxidativas de cadeias propílicas laterais, demetilação de grupos metoxilas e, às vezes, clivagem de anéis aromáticos (KIRK, $1983)$.

A não especificidade do sistema lignolítico em fungos de podridão branca é evidenciada pelos seguintes fatos:

a) a lignina é degradada, apesar da grande heterogeneidade das ligações entre unidades formadoras e da grande variedade de diferentes grupamentos vizinhos a estas 1 igações;

b) a lignina pode ser decomposta, mesmo depois de substancialmente modificada, como nos processos de polpação e branqueamento na indústria de papel e celulose; e

c) culturas lignolíticas podem metabolizar uma grande variedade de compostos aromát icos (KIRK, 1981).

Estudos com P. chrysosporium revelaram que o sistema 1 ignolítico não é induzido pela lignina, mas aparece quando as culturas entram num estágio de metabolismo secundário. Este início de atividade é estimulado pela limitação de hidratos de 
carbono, nitrogênio e enxofre e, aparentemente, a regulação deste metabolismo está ligada pelo metabolismo do glutamato (KIRK, 1981). JEFFRIES et alii (1981) sugerem que o fato da degradação da lignina ocorrer através de metabolismo secundário é uma evidência de que o crescimento primário não ocorre sobre a lignina, por razões de regulação, e que isto pode ser interpretado como conseqüência de que a degradação da lignina não fornece grande quantidade de energia para o fungo.

Poucos são os conhecimentos à respeito dos fatores ambientais, nutricionais e fisiológicos que influenciam a degradação microbiana da 1 ignina.

KIRK et alii (1983) relatam a existência de pesquisas mostrando que a decomposição da lignina por fungos de podridão branca requer, concomitantemente, o metabolismo de carboidratos, preferencialmente as hemiceluloses. Os níveis de nitrogênio e de carboidratos na madeira afetam a biodegradação da lignina por fungos (CRAWFORD \& CRAWFORD, 1984; KIRK et alii, 1976).

Segundo KIRK et alii (1978), a fonte de nitrogênio não apresenta influência significativa, mas sim a concentração desta substância é que determina efetivamente a taxa de degradação da lignina. Os autores sugerem três possibilidades para a inativação da degradação pelo nitrogênio:

a) a alta concentração de $N$, pode promover um decréscimo rápido do substrato de crescimento necessário para o metabolismo da 1 ignina; 
b) o metabolismo de nitrogênio compete com o metabolismo da lignina em alguns cofatores:

c) o nitrogênio atua regulando a síntese de um ou mais componentes deste sistema de degradação.

Outros aspectos devem ser estudados na degradação da lignina, pois os efeitos da podridão branca podem depender mais do tipo de madeira envolvido do que da espécie do fungo (KIRK \& HIGHLEY, 1973). Além disso, pode haver uma maior seletividade da podridão branca degradar folhosas do que coníferas. (HIGHLEY, 1976). DUCAM (sem data) citado pelo autor, propôs que diferenças anatômicas entre folhosas e coníferas foram a causa de resistência a degradação de coníferas por podridão branca em trabalho desenvolvido no Forest products Laboratory.

Segundo HALKETT et alii (1977) e KIRK \& CHANG (1975), devido ao fato da degradação da lignina ser um processo oxidativo, o oxigênio desempenha um papel fundamental. KIRK et alii (1978), estudando a relação entre o crescimento, esgotamento de carbono e decomposição de lignina por $P$. chrysosporium, sob uma atmosfera gasosa e variando as concentrações de oxigênio, observaram que atividade ocorre sob concentrações mais elevadas de oxigênio, independente da fonte de carbono.

\subsection{Enzimas Lignolíticas}

Três grupos de enzimas tem sido identificadas na degradação da lignina: ligninase, lacase e (Mn) peroxidase (Tabela 1 ). A ligninase é provavelmente a maior enzima e cataliza extensivas 
oxidações de substâncias não-fenólicas, além de unidades fenólicas da lignina (KIRK, 1988).

Tabela 1. Atividades das enzimas implicadas na degradação da lignina (KIRK, 1988)

\begin{tabular}{|c|c|c|}
\hline $\begin{array}{l}\text { Atividade } \\
\text { da enzima }\end{array}$ & $\begin{array}{l}\text { Cofatores/ } \\
\text { Substratos }\end{array}$ & Conseqüência da ação \\
\hline Ligninase & $\mathrm{H}_{2} \mathrm{O}_{2}$ & $\begin{array}{l}\text { Núcleos aromáticos oxidados } \\
\text { p/ radicais de cations }\end{array}$ \\
\hline Lacase & $\mathrm{O}_{2}$ & $\begin{array}{l}\text { Oxidação de fenóis para ra- } \\
\text { dicais de fenoxil }\end{array}$ \\
\hline Mn peroxidase & $\mathrm{H}_{2} \mathrm{O}_{2}, \mathrm{Mn}^{\mathrm{II}}$ & $\begin{array}{l}\text { MnII oxidado para MnII } \\
\text { (MnII oxida fenóis para } \\
\text { radicais de fenoxil) }\end{array}$ \\
\hline $\begin{array}{l}\mathrm{H}_{2} \mathrm{O}_{2} \text { produzido } \\
\text { por enzimas }\end{array}$ & $\begin{array}{l}\text { Substratos } \\
\text { orgânicos }\end{array}$ & $\mathrm{O}_{2}$ reduzido para $\mathrm{H}_{2} \mathrm{O}_{2}$ \\
\hline
\end{tabular}

A ligninase ativa foram recentemente detectadas nos seguintes fungos de podridão branca: $P$. chrysosporium (KIRK, 1983), Phlebia radiata (HATAKKA \& TERVILÃ, 1985), Panus tigrinus, (MALTSEVA et alii, 1986), Coriolus versicolor, Pleuroutus ostratus e Bjerkandera adusta, (WALDNER et alii, em comunicação pessoal para KIRK (1988)) e Lentinus edodes (OKI \& ISHIKAWA, 1986).

As duas enzimas lacase e (Mn) peroxidase oxidam somente unidades fenólicas da lignina. Com a segunda enzima descrita, ocorre a oxidação de Mnil para Mnili, que é o verdadeiro oxidante. $\mathrm{O}_{2} \mathrm{O}_{2}$ produzido por enzimas, fornece o $\mathrm{H}_{2} \mathrm{O}_{2}$ exigido pela ligninase e Mn peroxidase (KIRK, 1988). 
A ligninase ativa em $P$. chrysosporium é estimulada pela incubação das culturas com vários substratos a favor da enzima, incluindo o álcool vertril (3,4-dimetoxibenzil), que é um metabólito secundário deste fungo (FAISON et alii, 1986).

Segundo LEISOLA et ali $(1984)$, em $P$. chrysosporium o álcool veratril estimula a degradação de lignina a $\mathrm{CO}_{2}$ e compostos solúveis em água. FAISON et alii (1986), concluíram que o álcool veratril provavelmente funciona como um mecanismo via indução, porém afeta somente certas espécies de ligninases.

Recentes investigações têm mostrado que tanto a catase quanto o superóxido dismutase que destroem $\mathrm{H}_{2} \mathrm{O}_{2}$ e $\mathrm{O}_{2}$ inibem a degradação da lignina por $P$. chrysosporium. Atualmente não se possui, ainda, um modelo razoável do processo bioquímico de decomposição da lignina. O metabolismo dos produtos de baixa massa molecular derivados da degradação da lignina parece seguir os modelos metabólicos clássicos, envolvendo enzimas (KIRK, 1983).

\subsection{Métodos de Determinação de Lignina}

Vários métodos por determinação quantitativa de lignina e seus derivados têm sido descritos, incluindo as técnicas gravimétricas e espectrofotométricas (GARCIA \& LATGE, 1987). Segundo AMER \& DREW (1980) citados por VICENTE (1989) os métodos mais utilizados para a deteç̧ão de lignina e compostos relacionados são: (1) o método de ácido sulfúrico (KLASON), baseado na insolubilidade de lignina neste ácido; (2) o número KAPPA, responsável 
pela seletividade da lignina através da oxidação do permanganato de potássio; (3) cloração, avaliando o número de cloros substituídos na reação, e (4) espectrofotometria com absorção em luz ulta-violeta.

Outros métodos têm sido desenvolvidos, como a oxidação da lignina com nitrobenzeno em meio alcalino, formando a vanilina siringilaldeído e parahidroxibenzaldeído, para se identificar produtos de degradação da lignina (SARKANEN \& LUDWIG, 1971), aplicação de radioisótopos, utilizando lignina marcada com c14 como substrato (KIRK \& CHANG, 1975), método de formação de ácidos tioglicólicos de lignina insolúveis, em álcool (BROWNING, 1963), métodos qualitativos, como o Reação de cor de wiesner, usando floroglucinol em ácido clorídrico para reagir com os grupos coniferaldeídicos da lignina e Reação de Maule, onde só é positiva para ligninas contendo quantidades significativas de unidades de siringi 1-propano (FENGEL \& WEGENER, 1984), métodos de cromatografia para detectar a presença de produtos de degradação, ocorrência de peroxidases no meio e a seqüência da degradação da lignina na presença de metanol como produto de demetoxilação (BETTS \& DART, 1988; JANSHEKAR et alii, 1981; LEISOLA et alii, 1983). RAMACHANDRA et alii (1987) e SREBOTINIK et alii (1988) estabeleceram técnicas eletroforéticas em géis de poliacrilamida (PAGE) e dodecil sulfato de sódio-acrilamida (SDS - PAGE) e de Imumeletroforeses para a separação e caracterização de ligninases. Homoperoxidases foram identificadas utilizando-se antisoro para lignina peroxidase purificada de $P$. chrysosporium (LEISOLA et ali $i$, $1987)$. 
GARCIA \& LATGE (1987), desenvolveram técnicas de colorometria com florogluxinol para determinação da lignina de madeira contendo tecidos do fungo.

\subsection{Potenciais para a Indústria e o Processo de Biopolpaça}

Dentro da linha de pesquisa atual, nota-se um tendência para aplicação de microrganismos visando atender a indústria. Dentro da área específica de celulose, Cowling et alii (1978) afirmam que a celulose molecular remanescente de um ataque de podridão branca pode ser utilizada para produzir celulose de boa qualidade, bem como derivados, porém o mesmo não acontece com a podridão parda que degrada os polímeros de celulose a ponto de inutilizá-la já nos primeiros estágios de deterioração. Nota-se portanto a necessidade de seleção de populações de microrganismos desejáveis ao fim que se destina a madeira.

O estudo das propriedades da polpa mecânica, após o ataque de fungos degradadores, mostra ser promissor o processo biológico, seja através do crescimento micelial, seja pela via enzimática. Pesquisas com enzimas lignolíticas tem se mostrado eficientemente tanto na redução do consumo de energia, quanto no incremento das propriedades físico-mecânicas da polpa (BARRICHELO \& AUER, 1986).

Cavacos de Populus spp. tratados com o fungo Ceriporiopsis subvermispora, reduziu $20 \%$ de energia na polpação mecânica e $13 \%$ em cavacos de spruce sp. (SETLIFF et alii, 1990). 
Segundo AKHTAR et alii (1992) cavacos tratados com diferentes linhagens do fungo Ceriporiopsis subvermispora, promoveram incrementos nas propriedades de resistência e redução nas propriedades ópticas.

A utilização de fungos lignolíticos no pré-tratamento biológico para produção de celulose kraft tem sido pouco explorada. ORIARAN et alii (1990) estudaram o tratamento de cavacos de Populus tremuloides pelo fungo $P$. chrysosporium, incubados por 0 , 10. 20 e 30 dias. O rendimento em polpa foi aproximadamente $3 \%$ maior que o controle, para um mesmo número Kappa, após 30 dias de tratamento.

A degradação seletiva da lignina por determinados grupos de fungo vem sendo explorada, como um fator benéfico à polpação, seja pela remoção parcial da lignina, ou pela transformação deste polímero, de maneira a reduzir o consumo de energia na polpação mecânica; o consumo de reagentes químicos no processo kraft e incrementar as propriedades da polpa (KIRK et alii, 1983). 


\section{MATERIAL E MÉTODOS}

\subsection{Montagem da Pilha de Cavacos e Coleta de Amostras}

Madeira de $E$. grandis com idade de corte entre 5 e 7 anos, recém-abatida foi transformada em cavacos através de um picador e empilhada no meio de um talhão de $E$. grandis da fábrica da ARACRUz CELUlose S/A, na região de Aracruz, no estado do Espírito Santo.

Da tora até a forma de cavacos, a madeira passou pelos processos de lavagem da tora com águas residuais do licor do cozimento, descascamento, picagem e transporte por esteira até o pátio de armazenamento. Os cavacos foram transportados por caminhão até a plantação de $E$. grandis.

A pilha foi construída no dia $10 / 9 / 91$, na forma de pirâmide com um volume estimado de $2,6 \mathrm{~m}^{3}$ de cavacos e mantida até o fim de setembro/92.

A amostragem foi feita a partir de 4 pontos, norte, sul, leste e oeste na pilha, situados a altura de $1 \mathrm{~m}$, acima do solo. 
Coletas mensais foram feitas através da retirada de cerca de 2 quilos de cavacos da superfície da pilha em cada um dos pontos para a análise microbiológica, química, determinação de umidade e $\mathrm{pH}$.

Os cavacos coletados da pilha foram acondicionados em sacos plásticos de polietileno e fechados para se evitar a perda de umidade .

\subsection{Determinação do Teor de Umidade}

A determinação de umidade foi efetuada pela pesagem prévia dos cavacos úmidos, secagem em estufa a temperatura de $105 \pm$ $3^{\circ} \mathrm{C}$ por 12 horas no mínimo e posterior pesagem, obtendo-se a umidade percentual pela seguinte fórmula:

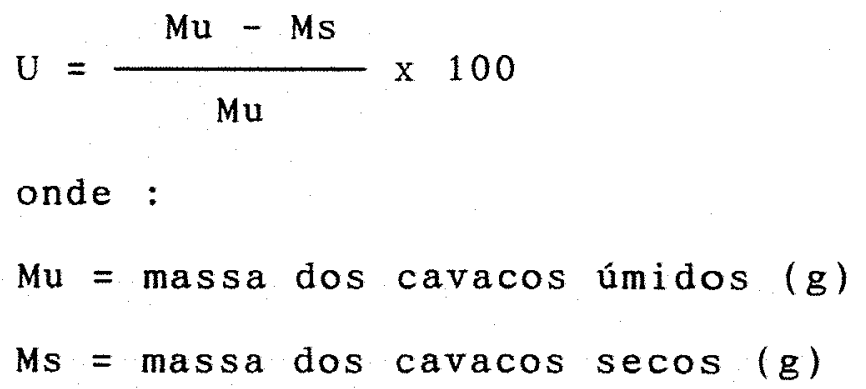

3.3. Determinação do pH

A metodologia para a medição do pH dos cavacos coletados foi baseada e adaptada de HATTON (1970). Pesou-se $100 \mathrm{~g}$ de cavacos úmidos coletados dos pontos de amostragem colocando-se em um 
frasco de Erlenmeyer de $500 \mathrm{ml}$ juntamente com $200 \mathrm{ml}$ de água destilada de $\mathrm{pH}$ entre 6,0 - 6,5. Logo em seguida o frasco foi colocado em um agitador, permanecendo por uma hora, sendo posteriormente filtrado e feita a medição em peagâmetro.

\subsection{Isolamento e Identificação dos Fungos}

o material coletado na pilha e transportado em sacos plásticos foi prontamente processado no laboratório do Departamento de Genética da ESALQ. Amostras coletadas e não analisadas, foram conservadas em câmara fria à $4^{\circ} \mathrm{C}$ até o processamento.

O método de amostragem dos cavacos baseou-se no estudo de SMITH \& OFOSU-ASIEDU (1972) citado por AUER (1986), no qual os cavacos foram retirados da pilha, homogeneizados e amostrados para isolamento, 100 cavacos ao acaso, por ponto de coleta.

Como técnica de isolamento, utilizou-se a de implantação de tecidos em meio-de-cultivo. Esta técnica consta da retirada de tecidos internos do cavaco de madeira com dimensões em torno de 2-3 mm de espessura e largura, com 8-10 mm de comprimento. Os tecidos retirados foram implantados em placas de petri contendo o meio Martin.

De cada cavaco foi retirado uma parte do tecido interno, sendo distribuídas 4 partes por placa de petri, utilizando-se no total 25 placas por lote de 100 cavacos. 
o isolamento dos fungos foi feito em dois lotes de cavacos: o primeiro lote continha cavacos esterilizados superficialmente pela flambagem com álcool (imersão em álcool $92^{\circ} \mathrm{GL} e$ queima). O outro lote continha cavacos não esterilizados.

Para a incubação dos cavacos, foi preparado o meio Martin (peptona universal, $15 \mathrm{~g} ; \mathrm{MgSO}_{4} .7 \mathrm{H}_{2} 0,0,5 \mathrm{~g} ; \mathrm{K}_{2} \mathrm{HPO}_{4}, 1 \mathrm{~g}$; dextrose, $10 \mathrm{~g}$; rosa bengala, $0,035 \mathrm{~g}$; sulfato de estreptomicina, $0,1 \mathrm{~g}$; ágar-ágar, $20 \mathrm{~g}$ e água destilada q.s.p. $1000 \mathrm{ml}$ ).

Todo o material, para incubação, foi colocado dentro de estufa controlada à temperatura de $28^{\circ} \mathrm{C}$, no escuro, por um período máximo de 72 horas, tempo suficiente para o aparecimento de todos os fungos presentes no tecido implantado sobre o meio de cultivo.

Cada grupo de fungo, a medida que o isolamento transcorreu foi purificado e mantido em tubos de ensaio com meio BDA (extrato de $200 \mathrm{~g}$ de batata; dextrose, $20 \mathrm{~g}$; ágar-ágar, $18 \mathrm{~g}$; água destilada q.s.p. $1000 \mathrm{ml}$ ), em câmara fria para futura identif icação.

No início do isolamento foi necessária uma pré-identificação dos fungos com base em suas características macro e microscópicas: morfologia e cultural.

Os isolados, com características filamentosas, pertencentes aos fungos, foram agrupados de acordo com o gênero que demonstrasse maior afinidade. 
A pré-identificação dos gêneros teve o auxílio do Prof. Tasso L. Krugner durante aulas de Micologia e utilização de literatura de vários pesquisadores que trabalharam com microrganismos, associados ou não a cavacos de madeira (APINIS, 1967; AUER, $1986 ;$ COONEY \& EMERSON, $1964 ;$ EMERSON, 1968; SCHIPPER, 1978 e TANSEY, 1971 ).

\subsection{Análises Químicas dos Cavacos Armazenados}

As análises foram efetuadas em seqüencia analítica de acordo com a metodologia utilizada nos laboratórios do setor de Química, Celulose e Energia (SQCE) do Departamento de Ciências Florestais da ESALQ/USP.

\subsubsection{Determinação de Extrativos da Madeira}

Os extrativos solúveis retirados por solventes orgânicos e água, incluem ácidos resinosos e graxos, além de seus ésteres, cêras, substâncias insaponificáveis, materiais coloridos e outros compostos.

Como não há solvente universal que remova todas essas substâncias, torna-se necessário um solvente seletivo para uma ou várias classes de extrativos.

\subsubsection{Extrativos Totais}

A determinação do teor de extrativos totais (extrativos solúveis em álcool-tolueno + extrativos solúveis em álcool + ex- 
trativos solúveis em água), foi efetuada pela pesagem prévia de o equivalente a $1,000 \mathrm{~g}$ absolutamente seco ( $\%$ a.s.) de serragem na fração de 40 mesh e transferida para cartucho de papel de filtro. os cartuchos foram colocados no extrator soxhlet e feitas extrações sucessivas de 8 horas cada, com mistura dé álcool-tolueno (1:2 em volume) e álcool $96^{\circ} \mathrm{GL}$.

Após a última extração e a secagem por $S$ horas ao ar, transferiram-se as serragens de cada cartucho para Erlenmeyer de $250 \mathrm{ml}$, mantendo a individualidade de cada um.

Foram adicionados $100 \mathrm{ml}$ de água destilada no Er lenmeyer e colocado em banho-maria a $100^{\circ} \mathrm{C}$. Após 3 horas filtrou-se através de cadinho de vidro sinterizado tarado, transferindo assim toda a serragem do Erlenmeyer para o cadinho. Esse cadinho foi seco em estufa $105 \pm 3^{\circ} \mathrm{C}$ até se obter peso constante.

Para cálculo, usou-se a seguinte fórmula:

$\% \mathrm{ET}=(1-\mathrm{MS}) \times 100$

onde:

$\%$ ET $=$ percentagem de extrativos totais

Ms = massa seca em estufa

\subsubsection{Extrativos Solúveis em $\AA$ lcool-Tolueno}

A determinação de extrativos solúveis em etanol-tolueno foi o seguinte: 
Secou-se o balão do aparelho extrator em estufa mantida a $105 \pm 30 \mathrm{C}$ até o peso constante. Com $2,000 \mathrm{~g}$ a.s. em cartucho de papel de filtro, transferido para aparelho de soxhlet, foi feita a extração com $200 \mathrm{ml}$ da solução de álcool-tolueno $(1: 2)$ por 8 horas. Evaporou-se o solvente do balão de extração e secou-se em estufa a $105 \pm 3^{\circ} \mathrm{C}$ até peso constante, logo após foi feita a pesagem do balão.

Fórmula usada para cálculo:

Eat $=\frac{M e}{M} \times 100$

onde:

: Eat = percentagem de produtos solúveis

Me = massa do extrator em grama

M = massa inicial da amostra a.s. em grama

\subsubsection{Extrativos em Diclorometano}

Nessa determinação usou-se o mesmo método de extração por álcool-tolueno, substituindo apenas a mistura álcool-tolueno por diclorometano.

\subsubsection{Determinação do Teor de Lignina}

A determinação do teor de lignina, foi efetuada pela pesagem prévia de o equivalente a $1,000 \mathrm{~g}$ absolutamente seco (\% a.s.) de serragem na fração de 40 mesh e transferência, para car- 
tucho de papel de filtro. Os cartuchos foram colocados no extrator Soxhlet e foram feitas as extrações sucessivas por 8 horas cada com mistura de álcool-tolueno $(1: 2)$, álcool $96^{\circ} \mathrm{GL}$ e 3 porções de água em ebulição, durante 3 horas.

Após a última extração e a secagem por 8 horas ao ar, transferiram-se as serragens de cada cartucho para copo de $50 \mathrm{ml}$, mantendo a individualidade de cada um.

Foram adicionados $15 \mathrm{ml}$ de $\mathrm{H}_{2} \mathrm{SO}_{4} 72 \%$ no copo e colocado em banho-maria a $18-20^{\circ} \mathrm{C}$. Após 2 horas de banho-maria a $20^{\circ} \mathrm{C}$, transferiu-se a amostra para Erlenmeyer de 1 litro usando $560 \mathrm{ml}$ de água destilada e colocado para ferver mantendo o nível da amostra constante com adição periódica de água. Depois de 4 horas deixou-se a lignina sedimentar totalmente e filtrou-se através de cadinho sinterizado tarado, transferindo assim toda a lignina do Erlenmeyer para o cadinho. Esse cadinho foi seco em estufa $105 \pm$ $3^{\circ} \mathrm{C}$ até se obter peso constante.

Para ocalculo, usou-se a seguinte fórmula:

$\% L=$ Massa residual 100

\subsubsection{Determinação do Teor de Holocelulose}

A determinação do teor de holocelulose, foi efetuada pela pesagem prévia de o equivalente a $2,000 \mathrm{~g}(\% \mathrm{a} . \mathrm{s}$.$) de serragem na$ fração 40 mesh e transferência para cartucho de papel de filtro. Nessa determinação usou-se o mesmo método de extração da lignina. 
Após a extração, a serragem foi transferida para Erlenmeyer de $125 \mathrm{ml}$. Foram adicionados $56 \mathrm{ml}$ de água, $3 \mathrm{ml}$ da solução $\mathrm{NaClO}_{2}$ e $2 \mathrm{ml}$ de ácido acético $(1: 5)$ e colocado em banho-maria a 70-80 $\mathrm{C}$. Após $45 \mathrm{minutos}$ adicionou-se mais $3 \mathrm{ml}$ de $\mathrm{NaClO}_{2}$ e $2 \mathrm{ml}$ de ácido acético. Essa operação foi repetida por quatro vezes a cada intervalo de 45 minutos.

Depois do último tratamento filtrou-se a amostra através de cadinho de vidro sinterizado tarado, com uma lavagem de $250 \mathrm{ml}$ de água destilada. Esse cadinho foi secado em estufa $105 \pm 3^{\circ} \mathrm{C}$ até se obter peso constante.

Para cálculo, usou-se a seguinte fórmula:

$$
\% H=\frac{\text { Massa residual }}{2,000} \times 100
$$

\subsection{Seleção de Fungos Lignolíticos}

Os fungos foram isolados diretamente de cavacos com podridão branca.

Todo material isolado em meio de BDA foi incubado em estufa controlada à temperatura de $28^{\circ} \mathrm{C}$, ao abrigo da luz, por um período máximo de 72 horas, quando então todos os fungos presentes apresentaram desenvolvimento.

Cada fungo, a medida que o isolamento transcorreu foi purificado e mantido em tubos de ensaio com meio BDA, dentro de câmara fria, para futura avaliação da atividade lignolítica. 


\subsection{Avaliação da Atividade Lignolítica}

\subsubsection{Obtenção do substrato de Lignina}

A obtenção da fração lignina a partir de serragem de Eucalyptus grandis, foi feita através do método klason (ABTCP M10/71; TAPPI $T 222-o m-83)$. Este método consiste no tratamento da amostra, livre de extrativos com ácido sulfúrico $72 \%$. ócido dissolve a fração polissacarídica, deixando como resíduo a lignina.

Após o substrato purificado, pesou-se $4 \mathrm{mg}, 8 \mathrm{mg}$ e $16 \mathrm{mg}$ e ressuspendeu-se em $\mathrm{NaOH} 0,55 \%$ e fez-se a leitura em espectrofotometro Micronal B-382. Os resultados obtidos foram comparáveis aos dados da leitura comprovando a obtenção da fração solúvel de lignina, utilizada como substrato no meio M.L.A. (item 3.7 .2 .1$.$) .$

\subsubsection{Inóculo e Cultivo}

Uma suspensão de conídios, diluída em salina para concentração de $8 \times 10^{6}$ conídios $/ m 1$, foi utilizada como inóculo em 5 ml de M.L.A. limitado de nitrogênio, obtido de acordo com item 3.7.2.1., na proporção de 1:1, distribuídos em Erlenmeyer de 500 ml, para maior aeração. Após o inóculo, incubou-se à temperatura ideal de cada fungo e, a cada intervalo de 24 horas, fez-se aeração com ar atmosférico em fluxo laminar. 


\subsubsection{Meio Utilizado Para o Cultivo dos Fungos em Estudo.}

Solucão A

$\mathrm{D}-\mathrm{glicose} \ldots \ldots \ldots \ldots \ldots \ldots \ldots \ldots \ldots \ldots \ldots \ldots$

$\mathrm{H}_{3} \mathrm{PO}_{4}(2 \mathrm{~N}) \ldots \ldots \ldots \ldots \ldots \ldots \ldots \ldots \ldots \ldots \ldots \ldots \ldots \ldots \ldots \ldots \ldots \ldots$

$\mathrm{NH}_{4} \mathrm{NO}_{3} \ldots \ldots \ldots \ldots \ldots \ldots \ldots \ldots \ldots \ldots \ldots \ldots \ldots \ldots \ldots \ldots \ldots, 496 \mathrm{~g}^{(*)}$

L. asparagina................... 0,890 g (**) $^{(*)}$

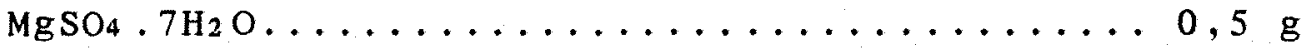

$\mathrm{CaCl}_{2} \cdot 2 \mathrm{H}_{2} \mathrm{O} \ldots \ldots \ldots \ldots \ldots \ldots \ldots \ldots \ldots \ldots \ldots \ldots \ldots \ldots \ldots$

$\mathrm{FeSO}_{4} \ldots \ldots \ldots \ldots \ldots \ldots \ldots \ldots \ldots \ldots \ldots \ldots \ldots \ldots \ldots \ldots \ldots$

Solução elementos traços.............. 1, 0 ml

Solução vitamina................... 1, o ml

Agua destilada..................500,0 ml

(**) Para meio limitado de nitrogênio

$\mathrm{NH}_{4} \mathrm{NO}_{3} \ldots \ldots \ldots \ldots \ldots \ldots \ldots \ldots \ldots \ldots \ldots \ldots \ldots \ldots, \ldots \ldots \ldots$

L. asparagina..................8,

\section{Solucão B}

Lignina..........................

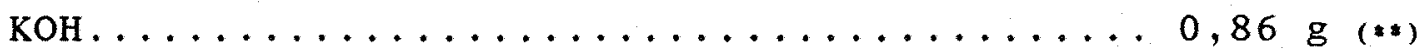

(*) Para meio limitado de nitrogênio

Lignina ......................... 1, o g

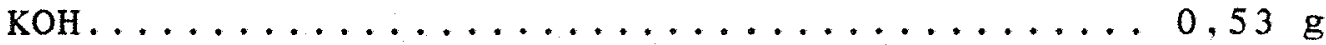

As soluções A e B foram autoclavadas separadamente. Depois foi adicionada A, lentamente, misturando com a solução. B. 
Para ofinal da solução, $50 \mathrm{ml}$ de solução tampão aquecida, foram adicionadas, via membrana de filtro estéril. O tampão consiste em uma solução de succinato de sódio 0,6 M (FENN \& KIRK, 1981, modificado) citado por VICENTE (1989).

\section{Solucão elemento traço}

Nitrato triacetato................

$\mathrm{MnSO}_{4} \cdot \mathrm{H}_{2} \mathrm{O} \ldots \ldots \ldots \ldots \ldots \ldots \ldots \ldots \ldots \ldots \ldots \ldots \ldots \ldots$

$\mathrm{CaCl}_{2}, 6 \mathrm{H}_{2} \mathrm{O} \ldots \ldots \ldots \ldots \ldots \ldots \ldots \ldots \ldots \ldots \ldots \ldots \ldots \ldots \ldots \ldots$

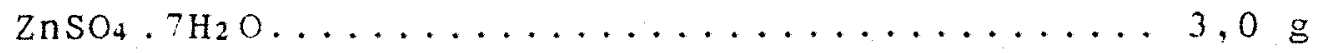

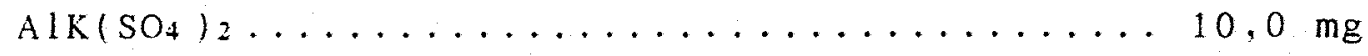

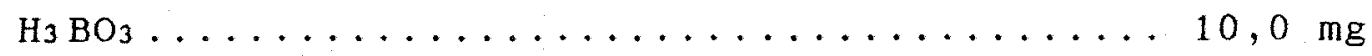

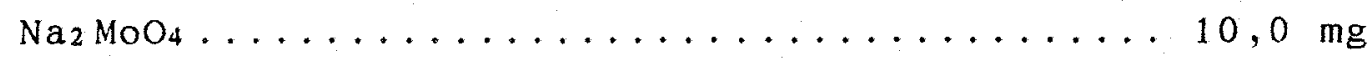

Agua destilada................... $1000 \mathrm{ml}$

\section{Solucão de vitaminas}

Biotina....................

Ácido p-amino benzóico................

Tiamina...................... 50,0 mg

Piridoxina..................... 100,0 mg

Acido nicotínico...................100,0 mg

Riboflavina......................... 100,0 mg

Agua destilada esterilizada.............100,0 ml

A solução foi esterilizada em banho-maria por 15 minutos e guardada no refrigerador a $4^{\circ} \mathrm{C}$ em frasco escuro sob clorofórmio. 


\subsubsection{Quantificação da Degradação da Lignina.}

A quantificação da degradação foi feita através de análise residual do substrato na absorbancia ultra violeta à $281 \mathrm{~nm}$ em espectofotômetro marca Micronal B-382 (VICENTE, 1989).

A cada frasco cultivado de acordo com o item anterior foram adicionados $30 \mathrm{ml}$ de $\mathrm{NaOH} 0,55 \%$, em seguida o conteúdo foi macerado por dez segundos e então foi centrifugado à 38.720 g por 15 minutos em centrífuga refrigerada. O sobrenadante foi precipitado em pH 3,0 com HCl, durante uma noite. Posteriormente a operação de centrifugação foi repetida e ressolubilizou-se o precipitado obtido em $5 \mathrm{ml}$ de solução de $\mathrm{NaOH} 4 \%$. Foram determinadas as quantidades de lignina presentes no início do cultivo, em intervalos a cada dois dias, durante dez dias. Em seguida foi determinada a porcentagem de lignina degradada e comparada com a degradação do fungo $P$. chrysosporium.

\subsection{Pré-Tratamento Biológico dos Cavacos}

\subsubsection{Microrganismos Utilizados}

P. chrysosporium, linhagem cedida pelo Dr. K. E. Eriksson (Laboratório STFI - Stockholm - Sweden).

Isolados Is1 (Fusarium sp.), Is 2 (Basidiomiceto (1)), Is 3 (Basidiomiceto (2)) e Is4 (Basidiomiceto (3)), selecionados pelo teste descrito no ítem 3.7.3. 
Os fungos destinados ao pré-tratamento biológico foram cultivados em $100 \mathrm{ml}$ de vermiculita, $50 \mathrm{ml}$ de água destilada e 50 ml de caldo de levedura e malte $(15 \mathrm{~g}$ de extrato de malte, $2 \mathrm{~g}$ de extrato de levedura e $1000 \mathrm{ml}$ de água destilada) e incubados a $30^{\circ} \mathrm{C}$ por 7 dias.

\subsubsection{Madeira Utilizada}

Para este experimento utilizou-se um lote de cavacos recém-picados de $E$. grandis, coletado na saída das peneiras de classificação da fábrica. O material foi posto para secar ao ar livre de modo a obter-se uma umidade final ao redor de $40 \%$.

\subsubsection{Inoculação dos Cavacos}

Após a secagem, cerca de $500 \mathrm{~g}$ de cavacos foram colocados em frascos de Erlenmeyer de $2000 \mathrm{ml}$ com tampa protegida com algodão de modo a permitir trocas gasosas e evitar contaminações com esporos de outros microrganismos. Para resolver o problema de umidade devido à longa incubação dos cavacos a $30^{\circ} \mathrm{C}$, foi colocada uma camada de esferas de vidro, $\operatorname{com} 1,7 \mathrm{~mm}$ de diâmetro cada, no fundo do frasco de Erlenmeyer, e através de um tubo plástico adaptado ao frasco, foram colocados após a autoclavagem, $100 \mathrm{ml}$ de água destilada esterilizada, mantendo assim a umidade dos cavacos durante os ensaios. 
o delineamento experimental constou de oito tratamentos, a saber:

- Tratamento T....: testemunha com 5 frascos contendo cavacos sem autoclavagem.

- Tratamento Ta...: testemunha com 5 frascos com cavacos autoclavados (esterilizados a $120^{\circ} \mathrm{C}$ durante uma hora).

- Tratamento IC...: 5 frascos com cavacos autoclavados e inoculados com $100 \mathrm{ml}$ de meio de cultura com vermicula e micélio vegetativo de $P$. chrysosporium.

- Tratamentos Isi, Is2, Is3 e Is4..: mesmo procedimento do tratamento (Ic), mas inoculando os fungos selecionados: Is1 = Fusarium; Is $2=$ Basidiomiceto(1); Is $3=$ Basidiomiceto(2); Is4 = Basidiomiceto(3).

- Tratamento Ist... : mesmo procedimento do tratamento (Ic), mas inoculando todos os fungos selecionados (IS1 + Is $2+\mathrm{ISS}_{3}+$ I s4)

Os tratamentos foram incubados a $30^{\circ} \mathrm{C}$ por um período de 60 dias. 


\subsection{Avaliação do Pré-Tratamento Biológico}

Após o período de incubação, as repetições dos respectivos tratamentos foram misturadas e homogeneizadas pela técnica de quarteamento, constituindo uma amostra composta por tratamento. As amostras compostas foram secadas ao ar durante quatro dias, acondicionadas em sacos de polietileno e mantidas em câmara fria $\left(4^{\circ} \mathrm{C}\right)$ até o processamento. A separação da vermiculita dos cavacos foi feita manualmente.

\subsubsection{Análises Químicas dos Cavacos Tratados.}

Cavacos secos ao ar foram moídos em moinho tipo Willey e determinou-se o teor de umidade. Para a determinação da composição química quantitativa a madeira foi analisada em termos de:

Teor de holocelulose

Teor de lignina

Teor de extrativos totais

Análises já descritas no ítem 3.5 .

\subsubsection{Densidade Básica}

A determinação da densidade básica dos cavacos tratados ou não, foi feita pelo método do Máximo Teor de Umidade (SMITH, 1954 ; FOELKEL et alii, 1975). 
Para isso, os cavacos foram submersos em água, sob vácuo até atingirem a saturação e, em seguida, foi determinada a densidade básica pela expressão:

$$
d_{b}=\frac{1}{\frac{M m-M a s}{M a s}+\frac{1}{G_{s}}}
$$

onde:

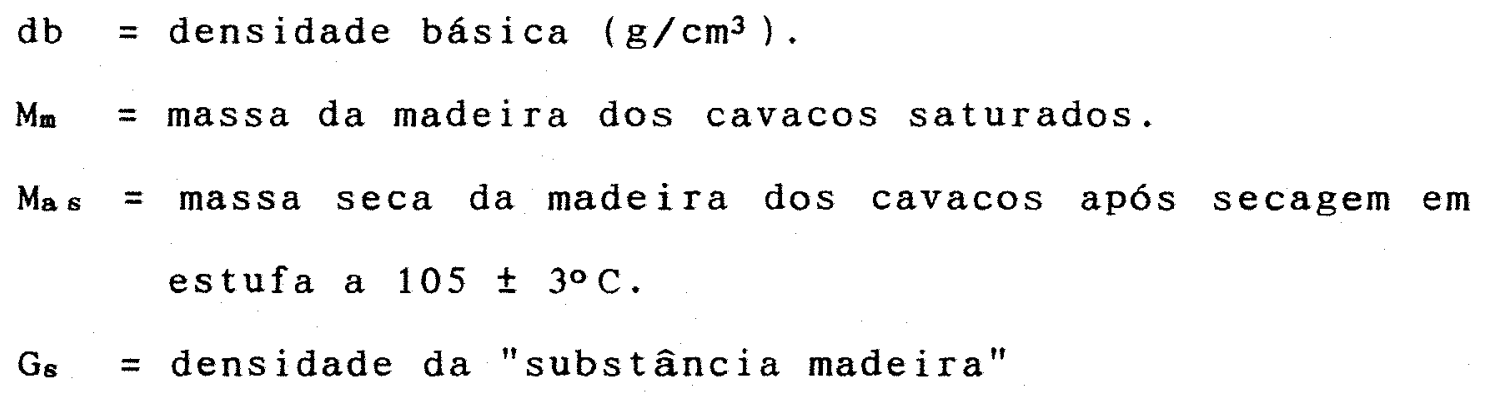

Admitindo-se que a densidade média da "substância madeira" é $1,53 \mathrm{~g} / \mathrm{cm}^{3}$, a expressão fica:

$$
\mathrm{db}_{\mathrm{b}}=\frac{1}{\frac{\mathrm{Mm}_{\mathrm{m}}}{\mathrm{Ma} \mathrm{s}_{\mathrm{s}}}-0,346}
$$

onde:

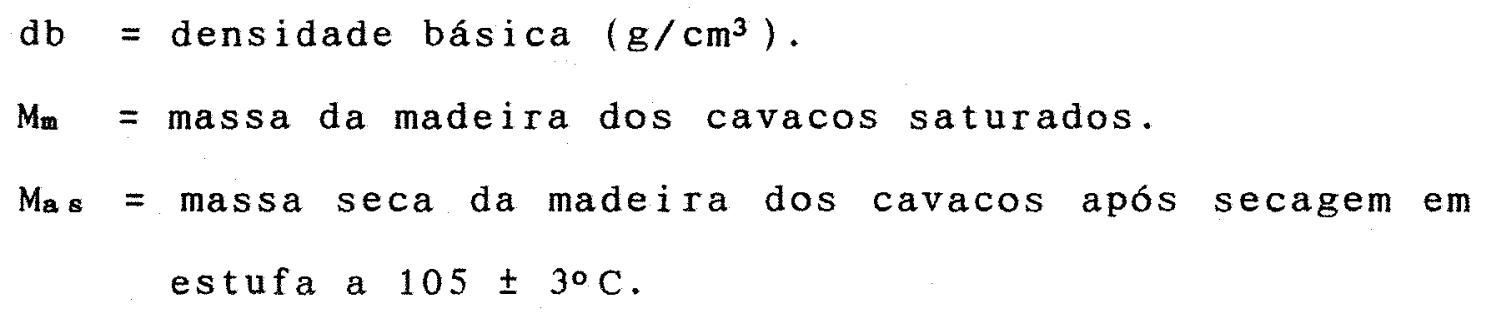




\subsection{Cozimentos Experimentais}

Para a obtenção de celulose foi empregado o processo sulfato. O cozimento foi executado em digestor de laboratório, de aço inoxidável, aquecimento direto, rotatório e com 20 litros de capacidade.

Os cavacos de cada um dos tratamentos, foram mantidos separados durante o cozimento, utilizando-se caixas de tela de aço inoxidável medindo 40 x $40 \times 90 \mathrm{~mm}$. Com isso permitiu-se a livre circulação do licor de cozimento entre os cavacos de diferentes tratamentos, simulando cozimentos convencionais, porém possibilitando-se as análises individualizadas dos resultados para cada tratamento. Utilizou-se uma quantidade total de madeira equivalente a 1.600 gramas absolutamente secos por cozimento.

Ainda tomou-se o cuidado de manter um mesmo nível de enchimento das caixas, e estas foram mantidas soltas no interior do digestor, possibilitando a movimentação durante o cozimento. Desta maneira procurou-se garantir que as condições de circulação de licor fossem as mais homogeneas possiveis entre os cavacos dos diferentes tratamentos.

As condições empregadas nos cozimentos foram as seguintes:

- Alcali ativo.................. 14\%

- sulfidez...................... 25\%

- Atividade......................100\%

- Relação licor madeira.......... 5: 1

- Temperatura máxima........... $170^{\circ} \mathrm{C}$ 
- Tempo até temperatura máxima......8 80 minutos

- Tempo à temperatura máxima........30 minutos

- Peso seco dos cavacos.........1.316,5 g

- Concentração Nazo ativo........243,8 g

Para a determinação do volume final de água a adicionar, levou-se em conta a umidade dos cavacos.

A celulose produzida foi peneirada em malha 120 e após uma lavagem, foi passada em um desfibrador de discos para individualização das fibras. A polpa foi lavada com água e retirou-se o excesso de água por compressão manual. A seguir, a polpa foi lavada e depurada em uma peneira com malha de 0,2 min para a separação dos rejeitos.

Nas amostras de polpa determinou-se:

a. Número Kappa...... : indicação do teor residual de lignina na celulose líndice de deslignificação). Por definição: número de mililitros de $\mathrm{KMnO}_{4}$ $0,1 \mathrm{~N}$ que reagem com $1 \mathrm{~g}$ a.s., de celulose sob condições padronizadas. O número Kappa é uma variação (aperfeiçoamento) do número de permanganato, cuja única diferença reside na metodologia de determinação. 


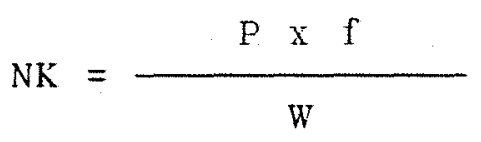

onde:

$f=$ fator de correção de $\mathrm{KMnO}_{4}$

$\mathrm{P}=\mathrm{ml}$ de $\mathrm{KMnO}_{4}$ 0,1 $\mathrm{N}$ consumidos pela polpa

$W=$ peso em gramas de celulose seca

b. Rendimento bruto...: (g. celulose bruta a.s. / g. ca$\operatorname{vacos}$ a.s.) $\times 100$

c. Rendimento depurado: (g. celulose bruta a.s. - g. a.s. rejeitos) $\times 100$

d. Rejeitos.......: matéria-prima subcozida e não desfibrada, nós ou qualquer material estranho que acompanha a celulose. Dada em $\%$ da celulose total após cozimento.

\subsection{Análise Estatística}

Os resultados das análises químicas dos cavacos armazenados foram comparados estatisticamente através dos testes F e Tukey ao nivel de $1 \%$ e $5 \%$ de probabilidade. 


\section{RESULTADOS E DISCUSSÃO}

\subsection{Monitoramento da Pilha de Cavacos}

A amostragem dos cavacos recém-picados, na montagem da pilha, apresentou o teor de umidade, igual a $41,3 \%$.

A umidade dos cavacos indicou valores próximos nos pontos amostrados, durante o armazenamento ao ar livre (Tabela 2). Notou-se uma tendência para perda de umidade com decorrer do tempo de armazenamento, acentuado pela falta de precipitações pluviométricas nos meses de junho, julho e agosto respectivamente aos 270,300 e 330 dias.

Os resultados obtidos para o teor de umidade dos cavacos são apresentados na Tabela 2 . 
Tabela 2. Valores médios de umidade dos cavacos (\%) coletados em quatro pontos externos da pilha de cavacos de Eucalyptus grandis, durante o armazenamento ao ar livre, em Aracruz/ES.

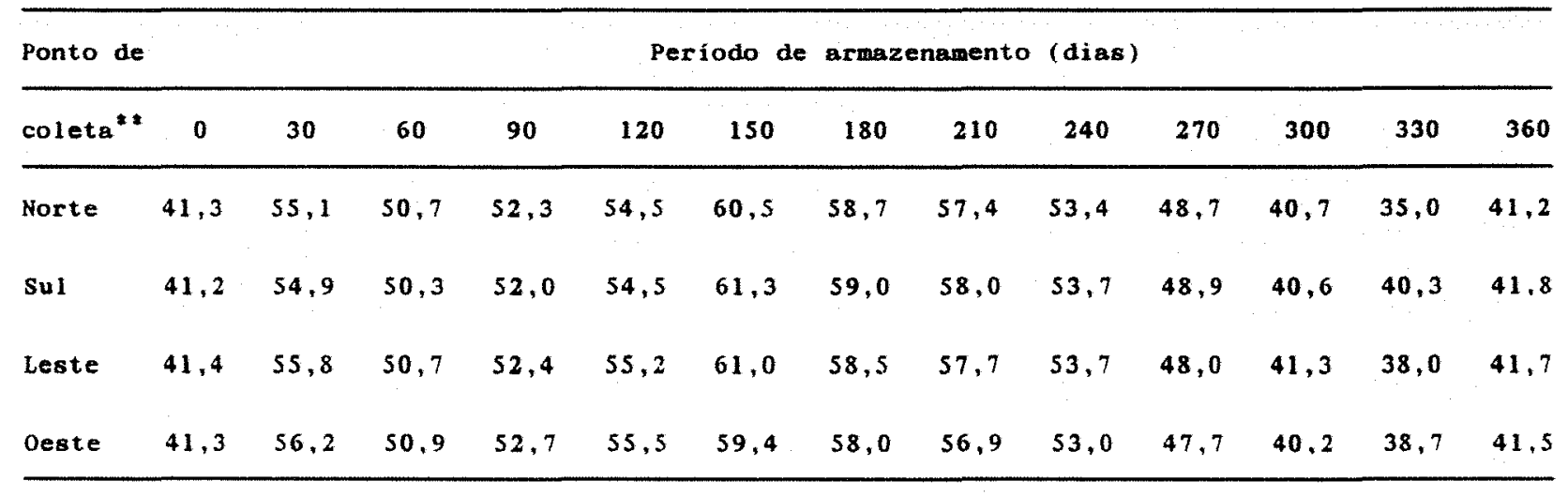

- o valor absoluto apresentado é média de três repeticões.

* Ponto de coleta: 1,0 m de altura acima do solo.

As variações da umidade dos cavacos em pilhas dependem das precipitações ocorridas no período de armazenamento e das dimensões das pilhas. Para pilhas pequenas ocorre a seguinte seqüência de eventos conforme BJORKMAN \& HAEGER (1963) e BOIS et alii (1962): durante a elevação inicial da temperatura, o teor de umidade no interior da pilha cai, enquanto o teor de umidade dos cavacos do topo e lados aumenta; quando a temperatura da pilha decresce, a umidade dos cavacos internos aumenta, de forma que em todas as partes da pilha, o teor de umidade passa a ficar mais ou menos constante. Nas grandes pilhas, em que a temperatura não cai como nas pequenas, a umidade dos cavacos internos permanece abaixo do que a dos cavacos superficiais.

4.2. $\mathrm{pH}$

Com relação ao pH da solução obtida dos cavacos, foi observada a tendência de decréscimo nos valores do pH com o aumento 
do período de armazenamento (Tabela 3). Segundo zocH et alii (1976) o abaixamento do valor do $\mathrm{pH}$ seria causado, por mudanças no número e tipo de microrganismos presentes na pilha e pela própria degradação da matéria orgânica.

Os valores médios de $\mathrm{pH}$ dos cavacos são apresentados na Tabela 3 .

Tabela 3. Valores médios* de pH dos cavacos coletados em quatro pontos externos da pilha de cavacos de Eucalyptus grandis, durante o armazenamento ao ar livre, em Aracruz/ES.

\begin{tabular}{|c|c|c|c|c|c|c|c|c|c|c|c|c|c|}
\hline \multirow{2}{*}{$\begin{array}{l}\text { Ponto de } \\
\text { coleta* }\end{array}$} & \multicolumn{13}{|c|}{ Periodo de armazenamento (dias) } \\
\hline & 0 & 30 & 60 & 90 & 120 & 150 & 180 & 210 & 240 & 270 & 300 & 330 & 360 \\
\hline Norte & 4,2 & 3,8 & 3,5 & 3,3 & 3,3 & 3,3 & 3,1 & 3,0 & 2,7 & 2,6 & 3,0 & 3,5 & 3,1 \\
\hline sul & 4,2 & 3,7 & 3,6 & 3,6 & 3,1 & 3,4 & 3,4 & 3,3 & 3,0 & 3,0 & 3,3 & 3,2 & 3,0 \\
\hline Leste & 4,2 & 3,5 & 3,3 & 3,3 & 3,0 & 3,1 & 3,1 & 3,2 & 2,8 & 2,7 & 3,0 & 3,0 & 3,5 \\
\hline Oeste & 4,2 & 3,5 & 3,5 & 3,5 & 3,3 & 2,9 & 3,0 & 3,0 & 2,6 & 2,8 & 3,4 & 3,0 & 3,4 \\
\hline
\end{tabular}

* O valor absoluto apresentado é média de três repetições.

* Ponto de coleta : 1,0 m de altura acima do solo.

A amostragem dos cavacos recém-picados, na montagem da pilha, apresentou o valor médio do $\mathrm{pH}$ igual a 4,2 .

Segundo SMITH \& OFOSU-ASIEDU (1972) a utilização do parâmetro pH poderia ser de caráter qualitativo da degradação dos cavacos, dado o consumo de componentes de madeira e transformação em ácidos orgânicos. 


\subsection{Isolamento e Identificação dos Fungos}

o levantamento da incidência de fungos na pilha de cavados recém picados e cavacos com vários períodos de armazenamento, estão mostrados nas tabelas 4,5 e 6 .

$\mathrm{Na}$ Tabela 4, estão expressas as incidências observadas em meio de cultivo, para os cavacos recém-picados.

Tabela 4. Incidência $(\%)^{*}$ de fungos isolados de cavacos de $E$. grandis recém-picados, sob dois métodos de isolamento e incubação em meio Martin (MMA) por 72 horas à $28^{\circ} \mathrm{C}$.

\begin{tabular}{l|c|c}
\hline \multirow{2}{*}{ Fungos } & \multicolumn{2}{|c}{ Métodos de Isolamento } \\
\cline { 2 - 3 } & Cavaco não Flambado & Cavaco Flambado \\
\hline Aspergileus & 4 & 1 \\
Penicielium & 1 & 1 \\
\hline
\end{tabular}

* o valor representa a porcentagem de fragmentos plaqueados, nos quais houve crescimento de fungos.

A metodologia empregada para o isolamento dos fungos e incubação dos cavacos recém-picados foi também utilizada para cavacos armazenados, sendo os dados sobre as freqüencias dos fungos isolados, de acordo com o gênero ou classe apresentados nas Tabelas 5 e 6 . 
Tabela 5. Freqüência (\%)* dos fungos em quatro pontos externos da pilha de cavacos de $E$. grandis, com vários períodos de armazenamento, isolados de cavacos não flambados e incubação em MMA por 72 horas a $28^{\circ} \mathrm{C}$.

\begin{tabular}{|c|c|c|c|c|c|c|c|c|c|c|c|c|c|}
\hline \multirow{2}{*}{ Fungos } & \multirow{2}{*}{$\begin{array}{l}\text { Ponto de } \\
\text { colelat }\end{array}$} & \multicolumn{12}{|c|}{ Periodo de armazenamento (clias) } \\
\hline & & 30 & 60 & 90 & 120 & 150 & 150 & 210 & 240 & 270 & 300 & 330 & 360 \\
\hline \multirow[t]{4}{*}{ Aspergili us sp. } & Norte & 70 & $6 \hat{3}$ & 80 & 62 & 50 & 37 & 30 & 19 & 12 & 10 & 10 & 5 \\
\hline & Sul & 77 & 71 & 69 & 57 & 67 & 48 & 39 & 19 & 15 & 7 & 3 & 6 \\
\hline & Leste & 68 & 52 & 61 & 45 & 50 & 35 & 22 & 13 & 7 & 5 & 5 & $s$ \\
\hline & oeste & 63 & 47 & 60 & 53 & 53 & 30 & 27 & 18 & 8 & 8 & 6 & 5 \\
\hline \multirow[t]{4}{*}{ Penicillium sp. } & Norte & 4.5 & 30 & 19 & 7 & $s$ & 10 & 7 & 2 & 1 & $s$ & 6 & 1 \\
\hline & SuI & 52 & 22 & 15 & 5 & 2 & 9 & 3 & 4 & 1 & 0 & 2 & 5 \\
\hline & Leste & 40 & 19 & 15 & 8 & 8 & 12 & 2 & 0 & 0 & 2 & 5 & 0 \\
\hline & Oeste & 58 & 1.3 & + & 2 & 4 & 10 & 0 & 0 & 0 & 2 & 5 & 3 \\
\hline \multirow[t]{4}{*}{ sporotrichum sp. } & Norte & 73 & 73 & 84 & 5.3 & 45 & $3 x$ & 32 & 10 & 3 & 3 & 3 & 0 \\
\hline & Sul & 68 & 72 & 70 & 45 & 40 & 38 & 28 & 9 & 4 & 3 & 0 & 0 \\
\hline & Leste & 64 & 60 & 52 & 31 & 25 & 27 & 19 & 5 & 3 & 4 & 2 & I \\
\hline & Deste & 75 & 67 & 48 & 50 & 48 & 39 & 2.5 & 7 & 6 & 2 & 1 & 3 \\
\hline \multirow[t]{4}{*}{ Rhizomucor sp. } & Norte & 42 & 25 & 10 & 12 & 10 & 5 & 1 & 0 & 0 & 0 & 0 & 0 \\
\hline & Sul & 36 & 25 & 15 & 8 & 10 & 7 & 1 & 0 & 0 & 0 & 0 & 0 \\
\hline & Leste & 5.5 & 28 & 12 & 13 & 9 & 8 & 1 & 0 & 0 & 0 & 0 & 0 \\
\hline & Deste & 43 & 20 & 7 & 0 & 4 & 2 & 0 & 0 & 0 & 0 & 0 & $\underline{0}$ \\
\hline \multirow[t]{4}{*}{ Botryosphaeria sp. } & Norte & 0 & 0 & 0 & 0 & 10 & 14 & 19 & 9 & 3 & 3 & 1 & 2 \\
\hline & Sul & 0 & 0 & 0 & 0 & 14 & 18 & 20 & 4 & 4 & 0 & 0 & 0 \\
\hline & Leste & 0 & 0 & 0 & 0 & 12 & 17 & 19 & 7 & 3 & 0 & 0 & 1 \\
\hline & Oeste & 0 & 0 & 0 & 0 & 5 & 9 & 13 & 3 & 4 & 1 & 0 & 0 \\
\hline \multirow[t]{4}{*}{ Fusarium sp. } & Norte & 0 & 0 & 0 & 0 & 0 & 2 & $s$ & 0 & 0 & 1 & 0 & 0 \\
\hline & Sul & 0 & 0 & 0 & 0 & 1 & 1 & 4 & 1 & 0 & 0 & 0 & 0 \\
\hline & Leste & 0 & 0 & 0 & 0 & 0 & 0 & 2 & 0 & 0 & 0 & 0 & 1 \\
\hline & Deste & 0 & 0 & 0 & 0 & 0 & 2 & $?$ & 4 & 0 & 1 & 0 & 0 \\
\hline \multirow[t]{4}{*}{ Trichoderma $\mathrm{sp}$} & Norte & 0 & 0 & 0 & 0 & 10 & 23 & 24 & 12 & 5 & 0 & 3 & 0 \\
\hline & SuI & 0 & 0 & 0 & 0 & 13 & 28 & 21 & 12 & 1 & 4 & 2 & 2 \\
\hline & Leste & 0 & 0 & 0 & 0 & 17 & 30 & 29 & 15 & 4 & 0 & $?$ & 1 \\
\hline & Oeste & 0 & 0 & 0 & 0 & 12 & 21 & 13 & 13 & 5 & 0 & 1 & 1 \\
\hline \multirow[t]{4}{*}{ Eurotium sp. } & Norte & 0 & 0 & 0 & 0 & 0 & 0 & 0 & 4 & 3 & 0 & 0 & 0 \\
\hline & Sul & 0 & 0 & $u$ & 0 & 0 & 0 & 1 & 3 & 3 & 0 & 0 & 0 \\
\hline & Leste & c & 0 & 0 & 0 & 0 & 0 & 0 & 3 & 0 & 0 & 0 & 0 \\
\hline & Deste & 0 & 0 & 0 & 0 & 0 & 0 & 0 & 0 & 0 & 0 & 0 & 0 \\
\hline \multirow[t]{4}{*}{ Basidiomiceto (1) } & Norte & 0 & 0 & 0 & 0 & 0 & 0 & 1 & 0 & 0 & 0 & 0 & 0 \\
\hline & Sul & 0 & 0 & 0 & 0 & 0 & 0 & 0 & 0 & 0 & 0 & 0 & 0 \\
\hline & Leste & 0 & 0 & 0 & 0 & 0 & 0 & 2 & 0 & 0 & 0 & 0 & 0 \\
\hline & Oeste & 0 & 0 & 0 & 0 & 0 & 0 & 0 & 2 & 0 & 0 & 0 & 0 \\
\hline \multirow[t]{4}{*}{ Basidiomiceto $(2)$} & Norte & 0 & 0 & 0 & 0 & 0 & 0 & 0 & 0 & 0 & 1 & 1 & 0 \\
\hline & sul & 0 & 0 & 0 & 0 & 0 & $\because 0$ & 0 & 1 & 0 & 0 & 0 & 0 \\
\hline & Leste & 0 & 0 & 0 & 0 & 0 & 0 & 0 & 0 & 0 & 0 & 1 & 0 \\
\hline & Oeste & 0 & 0 & 0 & 0 & 0 & 0 & 0 & 0 & 0 & 1 & 1 & 0 \\
\hline \multirow[t]{4}{*}{ Basidiomiceto (3) } & Norte & 0 & 0 & 0 & 0 & 0 & 0 & 0 & 0 & 0 & 0 & 0 & 0 \\
\hline & Sul & 0 & 0 & 0 & 0 & 0 & 0 & 0 & 0 & 0 & 0 & 0 & 0 \\
\hline & Leste & 0 & 0 & 0 & 0 & 0 & 0 & 0 & 0 & 0 & 0 & 0 & 0 \\
\hline & Deste & 0 & 0 & 0 & 0 & 0 & 0 & 0 & 0 & 0 & 0 & 0 & 0 \\
\hline
\end{tabular}

* O valor representa a porcentagem de fragmentos plaqueados nas quais houve crescimento de fungo. 
Tabela 6. Freqüência $(\%)^{*}$ dos fungos em quatro pontos externos da pillha de cavacos de $E$. grandis, com vários períodos de armazenamento, isolados de cavacos flambados $e$ incubação em MMA por 72 horas a $28^{\circ} \mathrm{C}$.

\begin{tabular}{|c|c|c|c|c|c|c|c|c|c|c|c|c|c|}
\hline \multirow{2}{*}{ Fungos } & \multirow{2}{*}{$\begin{array}{l}\text { Ponto de } \\
\text { colletet }\end{array}$} & \multicolumn{12}{|c|}{ Periodo de armazenamento (dias) } \\
\hline & & 30 & 60 & 90 & 120 & 1.50 & 180 & 210 & 240 & 270 & 300 & 330 & 360 \\
\hline \multirow[t]{4}{*}{ Aspergill us sp. } & Norte & 10 & 7 & 2 & 2 & 0 & 1 & 1 & 0 & 0 & 0 & 0 & 0 \\
\hline & Sul & $\ddot{\prime}$ & 3 & 2 & 1 & 0 & 0 & 0 & 0 & 0 & 0 & 0 & 0 \\
\hline & Leste & 11 & 5 & 1 & 0 & 0 & 2 & 0 & 2 & 0 & 0 & 0 & 0 \\
\hline & Deste & 15 & 8 & 3 & 2 & 0 & 0 & 0 & 0 & 0 & 0 & 0 & $\underline{0}$ \\
\hline \multirow[t]{4}{*}{ Penicillium sp. } & Norte & 13 & 2 & 2 & 1 & 0 & 1 & 3 & 2 & 0 & 0 & 0 & 0 \\
\hline & Sul & 10 & 1 & 0 & 0 & 0 & 4 & 1 & 2 & 2 & 0 & 1 & 2 \\
\hline & Leste & $s$ & 0 & 0 & 0 & 0 & 3 & 0 & 3 & 0 & 0 & 2 & 0 \\
\hline & Oeste & 10 & 1 & 0 & 1 & 0 & 0 & 3 & 0 & 2 & 0 & 0 & 2 \\
\hline \multirow[t]{4}{*}{ sporotrichum sp. } & Norte & 30 & 23 & 35 & 25 & 1.3 & 5 & 10 & 11 & 10 & 11 & 10 & 11 \\
\hline & Sul & 43 & 19 & 27 & 14 & 12 & 11 & 17 & 14 & 12 & 10 & 6 & 13 \\
\hline & Leste & 37 & 14 & 29 & 11 & 12 & 4 & 12 & 10 & 12 & 7 & 4 & 12 \\
\hline & Oeste & 29 & 7 & 22 & 20 & 15 & 4 & 15 & 10 & 12 & 3 & 2 & 8 \\
\hline \multirow[t]{4}{*}{ Rhizomucor sp. } & Norte & 1 & $\mathfrak{I}$ & 0 & 1 & 0 & 0 & 0 & 0 & 0 & 0 & 0 & 0 \\
\hline & SuI & 0 & 0 & 0 & 1 & 1 & 0 & 0 & 0 & 0 & 0 & 0 & 0 \\
\hline & Leste & 2 & 0 & 1 & 1 & 0 & 0 & 0 & 0 & 0 & 0 & 0 & 0 \\
\hline & Deste & 1 & 0 & 0 & 0 & 1 & 0 & 0 & 0 & 0 & 0 & 0 & 0 \\
\hline \multirow[t]{4}{*}{ Botryosphaeria sp. } & Norte & 0 & 0 & 0 & 0 & 0 & 4 & 12 & 12 & 4 & 0 & 0 & 0 \\
\hline & Sul 1 & 0 & 0 & 0 & 0 & 0 & 7 & 9 & 4 & 0 & 0 & 0 & 0 \\
\hline & Leste & 0 & 0 & 0 & 0 & 0 & 10 & 10 & 2 & 0 & 0 & 0 & 0 \\
\hline & Deste & 0 & 0 & 0 & 0 & 0 & 12 & 4 & 0 & 0 & 0 & 0 & $\underline{0}$ \\
\hline \multirow[t]{4}{*}{ Fusarium sp. } & Norte & 0 & 0 & 0 & 0 & 0 & 1 & 10 & 10 & 2 & 10 & 11 & 13 \\
\hline & Sul 1 & 0 & 0 & 0 & 0 & 0 & 0 & 2 & 10 & 4 & 12 & 12 & 10 \\
\hline & Leste & 0 & 0 & 0 & 0 & 0 & 0 & 7 & 11 & 6 & $\varepsilon$ & 10 & $s$ \\
\hline & Oeste & 0 & 0 & 0 & 0 & 0 & 0 & 4 & 9 & 3 & 13 & 8 & 7 \\
\hline \multirow[t]{4}{*}{ Trichoderma sp. } & Norte & 0 & 0 & 0 & 0 & 0 & 2 & 1 & 0 & 0 & 0 & 2 & 0 \\
\hline & SuI & 0 & 0 & 0 & 0 & 0 & 0 & 0 & 0 & 0 & 0 & 1 & 1 \\
\hline & Leste & 0 & 0 & 0 & 0 & 0 & 0 & 1 & 0 & 0 & 2 & 1 & 0 \\
\hline & Oeste & 0 & 0 & 0 & 0 & 0 & 1 & 1 & 0 & 0 & 1 & 2 & 0 \\
\hline \multirow[t]{4}{*}{ Eurotium sp. } & Norte & 0 & 0 & 0 & 0 & 0 & 0 & 0 & 2 & 2 & 0 & 0 & 0 \\
\hline & SuI & 0 & 0 & 0 & 0 & 0 & 0 & 1 & 4 & $\$$ & 0 & 0 & 0 \\
\hline & Leste & 0 & 0 & 0 & 0 & 0 & 0 & 0 & 0 & 7 & 0 & 0 & 0 \\
\hline & Deste & 0 & 0 & 0 & 0 & 0 & 0 & 0 & 2 & 8 & 0 & 0 & 0 \\
\hline \multirow[t]{4}{*}{ Basidiomiceto (1) } & Norte & 0 & 0 & 0 & 0 & 4 & 10 & 10 & 7 & 4 & 3 & 10 & 4 \\
\hline & Sul & 0 & 0 & 0 & 0 & $s$ & 13 & 9 & 2 & 3 & 4 & 12 & 3 \\
\hline & Leste & 0 & 0 & 0 & 0 & 3 & 11 & 7 & 5 & 12 & 5 & 8 & 2 \\
\hline & Oeste & 0 & 0 & 0 & 0 & 4 & 15 & 13 & 9 & 4 & 4 & .7 & 4 \\
\hline \multirow[t]{4}{*}{ Basidiomiceto (2) } & Norte & 0 & 0 & 0 & 0 & 0 & 12 & 15 & 5 & 4 & 4 & 2 & 3 \\
\hline & Sul & 0 & 0 & 0 & 0 & 0 & 14 & 14 & 7 & 6 & 6 & 1 & 6 \\
\hline & Leste & 0 & 0 & 0 & 0 & 0 & 21 & 18 & 7 & 7 & 7 & 0 & 2 \\
\hline & Oeste & 0 & 0 & 0 & 0 & 0 & 16 & 11 & 8 & 8 & 3 & 1 & 0 \\
\hline \multirow[t]{4}{*}{ Basidiomiceto ( 3 ) } & Norte & 0 & 0 & 0 & 0 & 0 & 0 & 0 & 0 & 0 & 0 & 3 & 3 \\
\hline & Su 1 & 0 & 0 & 0 & 0 & 0 & 0 & 0 & 0 & 0 & 0 & 4 & 4 \\
\hline & Leste & 0 & 0 & 0 & 0 & 0 & 0 & 0 & 0 & 0 & 0 & 2 & 4 \\
\hline & Deste & 0 & 0 & 0 & 0 & 0 & 0 & 0 & 0 & 0 & 0 & 0 & 4 \\
\hline
\end{tabular}

- O valor representa a porcentagem de fragmentos plaqueados nas quais houve crescimento de fungo. 
Foram isolados 11 fungos morfologicamente distintos. Notou-se uma sucessão de microrganismos durante o período de 12 meses de armazenamento. Segundo ANTUNES et ali $(1986)$, o desenvolvimento microbiano dá-se por etapas, marcadas pela metabolização de nutrientes e as competições entre os diversos grupos ocorrentes. Quanto a freqüência relativa de cada fungo, foram observados em maior freqüência, nos primeiros quatro meses, os fungos: Aspergillus, Sporotrichum, Penicillium e Rhizomucor, com tendência a decréscimo com aumento do período de armazenamento.

Após cinco meses de armazenamento dos cavacos aparecem os fungos Botryosphaeria, Fusarium, Trichoderma, Eurotium e três fungos da classe dos Basidiomicetos.

Segundo DICKINSON (1974) e DIEHM (1977) durante a degradação, o substrato modifica-se continuamente e isso, junto com a interação dos organismos entre si, resultando em sucessivas trocas nas populações de microrganismos decompositores da madeira.

Com desenvolvimento de fungos como Penicillium e Aspengillus, ocorre gradativamente diminuição na quantidade de açúcares simples facilmente metabolizáveis de modo que possa existir uma pressão ecológica no sentido de que sejam explorados os carboidratos da parede celular. Surge então, a dominância dos fungos de podridão mole. Estes fungos são Trichoderma, Eurotium, Botryosphaeria da classe Ascomicetos e Deuteromicetos, cujas as hifas desenvolvem-se dentro da parede celular e que decompõem fundamentalmente a celulose e hemicelulose (KAARIK, 1974; KAARIK, 
1975 ; LEVY \& DICKINSON, 1981 e SCHEFFER, 1973). Com o declínio da população dos fungos de podridão mole, ocorre o clímax da sucessão com a substituição por Basidiomicetos. Estes colonizam profundamente a madeira e decompõem os tecidos lenhosos numa velocidade normalmente bastante alta (LEPAGE, 1986).

Com o emprego da técnica de esterilização dos cavacos por flambagem, visou-se detectar quantitativamente e qualitativamente a presença de fungos na madeira, analisando-se sua capacidade em penetrar e se utilizar internamente da madeira como substrato. Essa esterilização externa dos cavacos resultou no aumento das frequências dos fungos da classe dos Basidiomicetos e do gênero Fusarium, indicando a capacidade de penetração da madeira, já que houve crescimento a partir dos tecidos internos, retirados dos cavacos.

4.4. Determinação dos Extrativos de Madeira

Os resultados encontrados para os valores médios em percentagem de extrativos totais são apresentados na Tabela 7 . 
Tabela 7. Valores médios do teor de extrativos totais (\%) de cavacos coletados em quatro pontos externos da pilha de cavacos de $E$. grandis, durante o armazenamento ao ar livre, em Aracruz/ES.

\begin{tabular}{|c|c|c|c|c|c|c|c|c|c|c|c|c|c|}
\hline \multirow{2}{*}{$\begin{array}{l}\text { Ponto de } \\
\text { coleta }\end{array}$} & \multicolumn{13}{|c|}{ Período de } \\
\hline & 0 & 1 & 2 & 3 & 4 & $s$ & 6 & 7 & 8 & 9 & 10 & 11 & 12 \\
\hline Norte & 5,68 & 5,02 & 4,13 & 4,00 & 3,82 & 3,92 & 3,45 & 4,02 & 5,35 & 5,80 & 6,02 & 6,15 & 6,58 \\
\hline $\mathrm{Sul}$ & 5,70 & $4,7.5$ & 4,22 & 4,32 & 4,02 & 3,98 & 3,50 & 4,13 & 4,58 & 5,76 & 6,10 & 6,23 & 6.59 \\
\hline Leste & 5,50 & 4,80 & 4,20 & 4,07 & 3,70 & 3,67 & 3,33 & 4,18 & 4,35 & 5,53 & 6,08 & 6,38 & 6,14 \\
\hline Oeste & 5,92 & 5,13 & 4,17 & 3,90 & 3,52 & 3,80 & 3,58 & 4,26 & 5,14 & 5,28 & 5,82 & 0,21 & 6,35 \\
\hline
\end{tabular}

* o valor percentual apresentado é média de três. repetições.

Tabela 8. Análise de variância dos valores médios do teor de extrativos totais (\%), nos diferentes períodos de armazenamento.

\begin{tabular}{lccccc}
\hline $\begin{array}{l}\text { Causas da } \\
\text { variação }\end{array}$ & G.L. & S.Q. & Q.M. & Valor F & Prob.>F \\
\hline Bloco & 3 & 0,2028519 & & & \\
Mês & 12 & 50,6290929 & 4,2190911 & $109,9737^{*}$ & 0,00001 \\
Resíduo & 36 & 1,3811232 & 0,0383645 & & \\
\hline Total & 51 & 52,2130679 & & \\
\hline
\end{tabular}

* Valores significativos ao nível de $1 \%$ Coeficiente de variação $=4,028 \%$ 
Tabela 9. Teste Tukey para médias dos valores de extrativos totais (\%), nos diferentes periodos de armazenamento.

\begin{tabular}{|c|c|c|c|}
\hline Mês & Médias originais" & $5 \%$ & $1 \stackrel{0}{\%}$ \\
\hline 12 & 6,415000 & a & A \\
\hline 11 & 6,242500 & $\mathrm{a}$ & $\mathrm{AB}$ \\
\hline 10 & 6,005000 & $a b$ & $\mathrm{ABC}$ \\
\hline 0 & 5,700000 & $\mathrm{~b}$ & $\mathrm{BC}$ \\
\hline 9 & 5,592500 & $\mathrm{~b}$ & $\mathrm{C}$ \\
\hline 1 & 4,925000 & $c$ & $\mathrm{D}$ \\
\hline$s$ & 4,855000 & c & $\mathrm{D}$ \\
\hline 2 & 4.180000 & $\mathrm{~d}$ & $E$ \\
\hline 7 & 4,147500 & $d$ & $E$ \\
\hline 3 & 4,072500 & $\mathrm{~d}$ & $\mathrm{E}$ \\
\hline 5 & 3,842500 & $\mathrm{de}$ & $\mathrm{EF}$ \\
\hline 4 & 3,765000 & $\mathrm{de}$ & $\mathrm{EF}$ \\
\hline 6 & 3,465000 & $e$ & F \\
\hline
\end{tabular}

* Médias seguidas por letras distintas diferem entre si ao nível de significância indicado.

DMS $5 \%=0,49163 ; \quad$ DMS $1 \%=0,57860$

Tabela 10. Valores médios do teor de extrativos solúveis em diclorometano (\%) de cavacos coletados em quatro pontos externos da pilha de cavacos de $E$. grandis, durante o armazenamento ao ar livre, em Aracruz/Es.

\begin{tabular}{|c|c|c|c|c|c|c|c|c|c|c|c|c|c|}
\hline \multirow{2}{*}{$\begin{array}{l}\text { Ponto de } \\
\text { coleta }\end{array}$} & \multicolumn{13}{|c|}{ Período de } \\
\hline & 0 & 1 & 2 & 3 & 4 & 5 & 6 & 7 & 8 & 9 & 10 & 11 & 12 \\
\hline Norte & 0,580 & 0,330 & 0,352 & 0,325 & 0,320 & 0,328 & 0,352 & 0,355 & 0,423 & 0,435 & 0,490 & 0,505 & 0,512 \\
\hline Sul & 0.602 & 0.325 & 0,345 & 0,317 & 0,313 & 0,333 & 0,355 & 0,385 & 0,438 & 0,482 & 0.483 & 0.508 & 0,535 \\
\hline Leste & 0.600 & 0,333 & 0,351 & 0,313 & 0,317 & 0,358 & 0,373 & 0,402 & 0,451 & 0,485 & 0,450 & 0,480 & 0,524 \\
\hline Oeste & 0,618 & 0,327 & 0,337 & 0,310 & 0,311 & 0.364 & 0,364 & 0,400 & 0,462 & 0,444 & 0,495 & 0,498 & 0,512 \\
\hline
\end{tabular}

* o valor percentual apresentado é média de três repetições. 
Tabela 11. Análise de variância dos valores médios do teor de extrativos solúveis em diclorometano $(\%)$, nos diferentes períodos de armazenamento.

\begin{tabular}{lccccc}
\hline $\begin{array}{l}\text { Causas da } \\
\text { variação }\end{array}$ & G.L. & S.Q. & Q.M. & Valor $F^{* *}$ & Prob.>F \\
\hline Bloco & 3 & 0,0020796 & & & \\
Mês & 12 & 0,3910856 & 0,0325905 & $126,3893^{* *}$ & 0,00001 \\
Resíduo & 36 & 0,0092829 & 0,0002579 & & \\
\hline Total & 51 & 0,4024481 & & & \\
\hline
\end{tabular}

* Valores significativos ao nível de $1 \%$ Coeficiente de variação $=3,877 \%$

Tabela 12. Teste Tukey para médias dos valores de extrativos solúveis em diclorometano $(\%)$, nos diferentes períodos de armazenamento.

\begin{tabular}{|c|c|c|c|}
\hline Mês & Médias originais & $5 \%$ & $1 \%$ \\
\hline 0 & 0,600000 & $\mathrm{a}$ & $A$ \\
\hline 12 & 0,517250 & $\mathrm{~b}$ & $\mathrm{~B}$ \\
\hline 11 & 0,497000 & $\mathrm{bc}$ & $\mathrm{BC}$ \\
\hline 10 & 0,476500 & $c d$ & $\mathrm{BCD}$ \\
\hline 9 & 0,451500 & $\mathrm{~d}$ & $\mathrm{CD}$ \\
\hline 8 & 0,443500 & $d$ & $\mathrm{D}$ \\
\hline 7 & 0,385500 & e & $\mathrm{E}$ \\
\hline 6 & 0,361000 & ef & $E F$ \\
\hline 2 & 0,346250 & ef $g$ & $E F$ \\
\hline 5 & 0,345750 & e $f g$ & $\mathrm{EF}$ \\
\hline 1 & 0,328750 & $f g$ & $F$ \\
\hline 3 & 0,316250 & $g$ & $\mathrm{~F}$ \\
\hline 4 & 0,315250 & $\mathrm{~g}$ & $F$ \\
\hline
\end{tabular}

* Médias seguidas por letras distintas diferem entre si ao nível de significância indicado.

DMS 5\% $\%$ o, $04031 ; \quad$ DMS $1 \%=0,04744$ 
Tabela 13. Valores médios* do teor de extrativos solúveis em álcool-tolueno $(1: 2)$ (\%) de cavacos coletados em quat ro pontos externos da pilha de cavacos de $E$. gnandis, durante o armazenamento ao ar livre, em Aracruz/ES.

\begin{tabular}{|c|c|c|c|c|c|c|c|c|c|c|c|c|c|}
\hline \multirow{2}{*}{$\begin{array}{l}\text { Ponto de } \\
\text { coleta }\end{array}$} & \multicolumn{13}{|c|}{ Período de } \\
\hline & 0 & 1 & 2 & 3 & 4 & 5 & 6 & 7 & 8 & 9 & 10 & 11 & 12 \\
\hline Norte & 3,00 & 2,06 & 1,94 & 1,54 & 1,26 & 1,23 & 1,32 & 1,48 & 1,58 & 1,64 & 1,80 & 2,02 & 2,58 \\
\hline $\mathrm{Sul}$ & 2,87 & 2,12 & 2,02 & 1,59 & 1,15 & 1,30 & 1,30 & 1,46 & 1,53 & 1,68 & 1,98 & 2.14 & 2.64 \\
\hline Leste & 3,02 & 2,17 & 2,10 & 1,36 & 1,11 & 1,10 & 1,15 & 1,37 & 1,48 & 1,70 & 1.75 & 2.05 & 2,22 \\
\hline Oeste & 2,51 & 2.22 & 2,03 & 1,31 & 1,14 & 1,12 & 1.18 & 1.30 & 1,40 & 1.6 .5 & 1.82 & 1,98 & 2.14 \\
\hline
\end{tabular}

* O valor percentual apresentado é média de 3 repetições.

Tabela 14. Análise de variância dos valores médios do teor de extrativos solúveis em álcool-tolueno (\%), nos diferentes períodos de armazenamento.

\begin{tabular}{lccccc}
\hline $\begin{array}{l}\text { Causas da } \\
\text { variação }\end{array}$ & G.L. & S.Q. & Q.M. & Valor F & Prob.>F \\
\hline Bloco & 3 & 0,1575904 & & & \\
Mês & 12 & 12,5817500 & 1,0484792 & $86,6045^{*}$ & 0,00001 \\
Residuo & 36 & 0,4358346 & 0,0121065 & & \\
\hline Total & 51 & 13,1751750 & & \\
\hline
\end{tabular}

* Valores significativos ao nível de $1 \%$ Coeficiente de variação $=6,243 \%$ 
Tabela 15. Teste Tukey para médias dos valores de extrativos solúveis em álcool-tolueno (\%), nos diferentes períodos de armazenamento.

\begin{tabular}{|c|c|c|c|}
\hline Mês & Médias originais & $5 \%$ & $1 \%$ \\
\hline 0 & 2,850000 & $\mathbf{a}$ & A \\
\hline 12 & 2,395000 & $b$ & B \\
\hline 1 & 2,142500 & $\mathrm{bc}$ & $\mathrm{BC}$ \\
\hline 11 & 2,057500 & $c d$ & $\mathrm{C}$ \\
\hline 2 & 2,022500 & $\mathrm{~cd}$ & $\mathrm{C}$ \\
\hline 10 & 1,837500 & de & $\mathrm{CD}$ \\
\hline 9 & 1,655000 & ef & $\mathrm{DE}$ \\
\hline 8 & 1,497500 & $\mathrm{fg}$ & $\mathrm{EF}$ \\
\hline 3 & 1,450000 & $\mathrm{fgh}$ & EFG \\
\hline 7 & 1,402500 & fghi & $\mathrm{EFG}$ \\
\hline 6 & 1,237500 & $\mathrm{ghi}$ & FG \\
\hline 5 & 1,200000 & $\mathrm{hi}$ & FG \\
\hline 4 & 1,165000 & i & G \\
\hline
\end{tabular}

- Médias seguidas por letras distintas diferem entre si ao nível de significância indicado.

DMS $5 \%=0,27617 ; \quad$ DMS $1 \%=0,32503$

Nos valores apresentados nas Tabelas 7,9 e 13 observa-se queda nos teores de extrativos, com um aumento destes teores nos últimos meses de armazenamento. Através da análise de variância (Tabelas 8,11 e 14), verificou-se que houve diferenças significativas nos tratamentos citados. Pelo teste Tukey (Tabelas 9, 12 e 15$)$, detectou-se diferenças nos tratamentos.

Analisando-se os resultados obtidos na determinação de extrativos pode-se observar uma queda nos extrativos até ao quarto mês de armazenamento, independentemente do ponto de coleta dos cavacos. Esses resultados têm sido registrado por vários autores, demonstrando inclusive a capacidade degradativa de arabi- 
nose, xilose e pectatos (FLANNIGAN \& SELLARS, 1972; ADAMS \& DEPLOY, 1978; OBERT, 1979 e AUER et alii, 1986). O aumento dos teores de extrativos estaria ligado a degradação enzimática promovida por hemicelulases produzidas pelos fungos (TAN, 1987 ). KIRK et alii (1983) relatam a existência de pesquisas mostrando que a degradação da 1 ignina por fungos de podridão branca requer, concomitantemente, o metabolismo de carboidratos, preferencialmente as hemiceluloses. Com o aparecimento no meio dos produtos intermediários da decomposição orgânica criou-se condições para proliferação de outros grupos capazes de utilizar os compostos secundários.

\subsection{Determinação dos Teores de Lignina e Holocelulose}

Os resultados encontrados para os valores médios em percentagem de teores de lignina e holocelulose são apresentados nas Tabelas 16 e 19 .

Tabela 16. Valores médios do teor de lignina (\%) de cavacos coletados em quatro pontos externos da pilha de cavacos de $E$. grandis, durante o armazenamento ao ar livre, em Aracruz/ES.

\begin{tabular}{|c|c|c|c|c|c|c|c|c|c|c|c|c|c|}
\hline \multirow{2}{*}{$\begin{array}{l}\text { Ponto de } \\
\text { coleta }\end{array}$} & \multicolumn{13}{|c|}{ Período de } \\
\hline & 0 & 1 & 2 & 3 & 4 & 5 & 6 & 7 & 8 & 9 & 10 & 11 & 12 \\
\hline Norte & 25,06 & 24,87 & 24,96 & 24,86 & 24,70 & 24,12 & 23,94 & 23,35 & 22,08 & 21,90 & 20,14 & 20,07 & 19,87 \\
\hline Su 1 & 25,10 & 25,01 & 24,92 & 24,46 & 24,18 & 24,08 & 23,76 & 23,19 & 22,12 & 21,01 & 20,07 & 20,03 & 19,56 \\
\hline Leste & 25,05 & 25,03 & 24,20 & 24,18 & 24,43 & 24,07 & 23,89 & 23,24 & 22,14 & 21,08 & 19,97 & 20,02 & 19,73 \\
\hline Oeste & 24,91 & 24,88 & 24,36 & 24,74 & 24,58 & 24,15 & 23,55 & 23,13 & 22,03 & 21,75 & 20,12 & 20,09 & 19,13 \\
\hline
\end{tabular}

* o valor percentual apresentado é média de 3 repetições. 
Tabela 17. Análise de variância dos valores médios do teor de lignina (\%), nos diferentes periodos de armazenamento.

\begin{tabular}{lccccc}
\hline $\begin{array}{l}\text { Causas da } \\
\text { variação }\end{array}$ & G.L. & S.Q. & Q.M. & Valor F & Prob.>F \\
\hline Bloco & 3 & 0,4258854 & & & \\
Mês & 12 & 196,4763658 & 16,3730305 & $356,8049^{*}$ & 0,00001 \\
Resíduo & 36 & 1,6519647 & 0,0458879 & & \\
\hline Total & 51 & 198,5542159 & & \\
\hline
\end{tabular}

* Valores significativos ao nível de $1 \%$ Coeficiente de variação $=0,935 \%$

Tabela 18. Teste Tukey para médias dos valores de teor de lignina nos diferentes periodos de armazenamento.

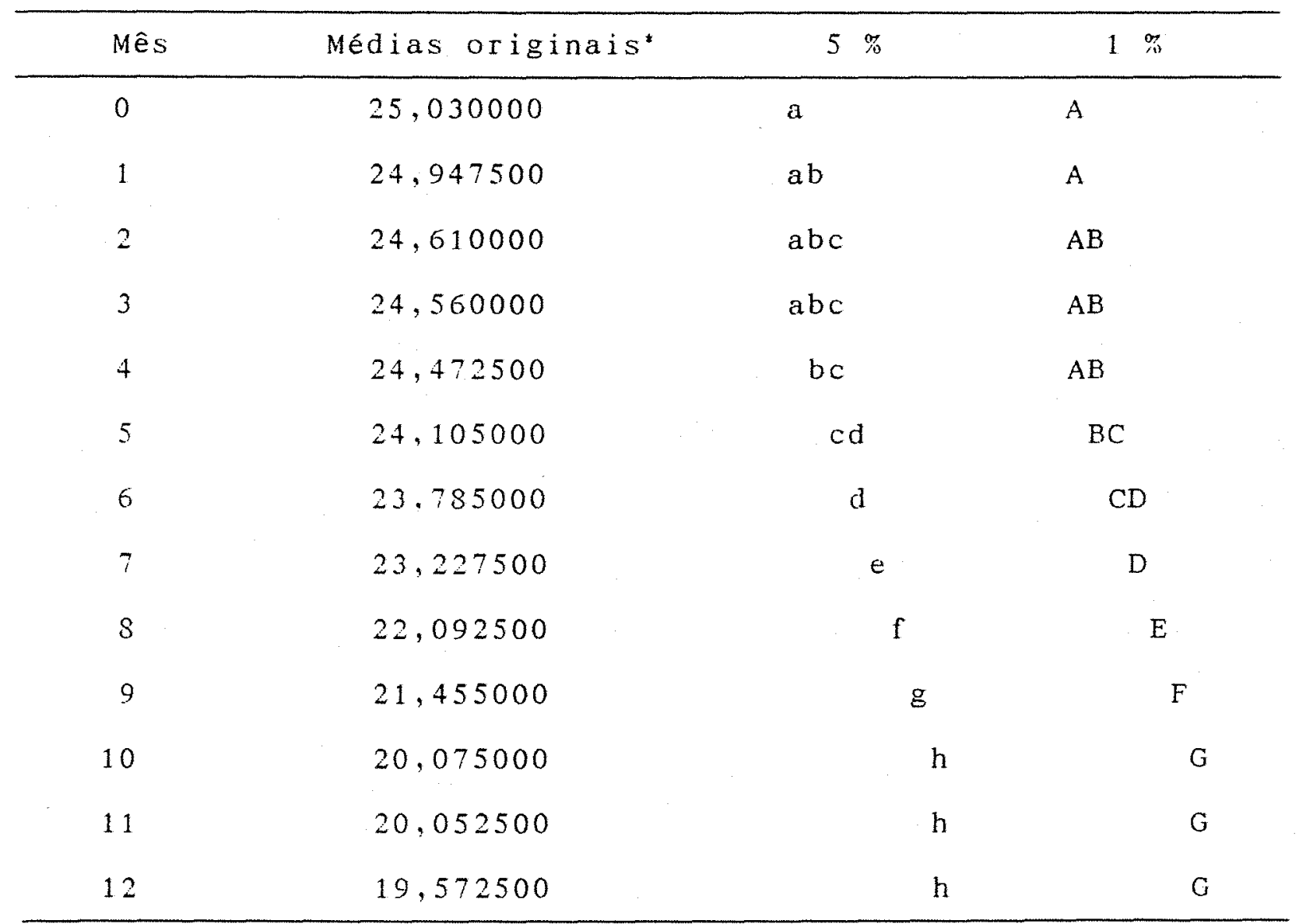

* Médias seguidas por letras distintas diferem entre si ao nível de significância indicado.

DMS $5 \%=0,53768 ; \quad$ DMS $1 \%=0,63279$ 
Tabela 19. Valores médios* do teor de holocelulose (\%) de cavacos coletados em quatro pontos externos da pilha de cavacos de $E$. grandis, durante o armazenamento ao ar $1 \mathrm{i}$ vre, em Aracruz/ES.

\begin{tabular}{|c|c|c|c|c|c|c|c|c|c|c|c|c|c|}
\hline \multirow{2}{*}{$\begin{array}{l}\text { Ponto de } \\
\text { coleta }\end{array}$} & \multicolumn{13}{|c|}{ Período de armazenamento (mês) } \\
\hline & 0 & 1 & 2 & 3 & 4 & 5 & 6 & 7 & 8 & 9 & 10 & 11 & 12 \\
\hline Norte & 71.04 & 70,50 & 70,23 & 70,42 & 70,16 & 70,08 & 70,02 & 68,20 & 68.17 & 68,01 & 66,14 & 65,04 & 63,14 \\
\hline Su 1 & $\pi 1.08$ & 70,47 & 70,14 & 70,38 & 70,50 & 70.35 & 70,08 & 69,40 & 68,98 & 67,97 & 66,98 & 64,54 & 62,62 \\
\hline Leste & 71,07 & 70,53 & 70,25 & 70,27 & 70,48 & 70,50 & 70,12 & 69,75 & 68,53 & 67,81 & 66,15 & 64,28 & 63,22 \\
\hline Oeste & 70.85 & 70,57 & 70,13 & 70,23 & 70,10 & 70.08 & 70.05 & 69.14 & 68.12 & 67.53 & 66,57 & 64,64 & 63,02 \\
\hline
\end{tabular}

* O valor percentual apresentado é média de 3 repetições.

Tabela 20. Análise de variância dos valores médios do teor de holocelulose (\%), nos diferentes períodos de armazenamento.

\begin{tabular}{lccccc}
\hline $\begin{array}{l}\text { Causas da } \\
\text { Variação }\end{array}$ & G.L. & S.Q. & Q.M. & Valor F & Prob.>F \\
\hline Bloco & 3 & 0,3736983 & & & \\
Mês & 12 & 301,7437922 & 25,1453160 & $308,3854^{* *}$ & 0,00001 \\
Resíduo & 36 & 2,9353903 & 0,0815386 & & \\
\hline Total & 51 & 305,0528808 & & \\
\hline
\end{tabular}

* Valores significativos ao nível de $1 \%$ Coeficiente de variação $=0,416 \%$ 
Tabela 21. Teste Tukey para médias dos valores de teor de holocelulose nos diferentes períodos de armazenamento.

\begin{tabular}{|c|c|c|c|}
\hline Mês & Médias originais & $5 \%$ & $1 \%$ \\
\hline 0 & 71,010000 & a & A \\
\hline 1 & 70,517500 & $a b$ & $A B$ \\
\hline 2 & 70,324999 & $a b$ & $\mathrm{AB}$ \\
\hline 3 & 70,310001 & $a b$ & $\mathrm{AB}$ \\
\hline 4 & 70,252501 & $\mathrm{~b}$ & $\mathrm{AB}$ \\
\hline 5 & 70,195000 & $b$ & $\mathrm{AB}$ \\
\hline 6 & 70,067501 & $\mathrm{~b}$ & $\mathrm{~B}$ \\
\hline 7 & 69,122499 & c & C \\
\hline 8 & 68,437502 & $\mathrm{~cd}$ & $\mathrm{CD}$ \\
\hline 9 & 67,830000 & $\mathrm{~d}$ & $\mathrm{D}$ \\
\hline 10 & 66,460001 & $\epsilon$ & $E$ \\
\hline 11 & 64,625000 & & $\mathrm{~F}$ \\
\hline 12 & 63,000000 & & $\mathrm{G}$ \\
\hline
\end{tabular}

* Médias seguidas por letras distintas diferem entre si ao nível de significância indicado.

DMS $5 \%=0,53768 ; \quad$ DMS $1 \%=0,63279$

Anal isando-se os resultados apresentados nas Tabelas 16 e 19, observa-se queda nos teores de lignina e holocelulose, independentemente do ponto de coleta dos cavacos. Através da análise de variância (Tabelas 17 e 19), verificou-se que houve diferenças significativas nos tratamentos citados. Pelo teste Tukey (Tabelas 18 e. 21), detectou-se diferença a partí do 60 mês de armazenamento.

De acordo com os teores de lignina e holocelulose podemos observar uma queda a partir do aparecimento dos Basidiomicetos 
isolados. Segundo ANDER \& ERIKSSON (1977), alguns Basidiomicetos apresentam um potencial efetivo na degradação de lignocelulose, possuindo a capacidade de degradar celulose e hemicelulose, produzindo peroxidases extracelulares envolvidas na degradação da lignina. KIRK (1981), relata que o sistema lignolítico não é induzido pela lignina mas aparece quando as culturas entram num estágio de metabolismo secundário. Este início de atividade é estimulado pela limitação de hidratos de carbono, nitrogênio e enxofre e aparentemente, a regulação deste metabolismo está ligada ao metabolismo do glutamato.

4.6. Seleção dos Fungos Lignolíticos.

Com base nos isolamentos efetuados em cavacos com podridão branca, foram encontrados seis fungos: Botryosphaeria, Fusarium, Sporotrichum, Basidiomiceto (1), Basidiomiceto (2) e Basidiomiceto (3).

\subsubsection{Determinação da Atividade Lignolítica.}

Nesse experimento, a lignina utilizada como substrato foi extraída de serragem de $E$. grandis, sendo que o sobrenadante originado desta extração apresentou uma maior absorção a $281 \mathrm{~nm}$. Esta observação foi relatada por CARRAU et alii (1987) como característica do polímero lignina. 
A Tabela 22 apresenta os resultados em absorbância da degradação de lignina, indicando em percentagem a degradação total deste polímero para cada fungo avaliado.

Tabela 22. Atividade lignolítica dos fungos isolados, e da linhagem de $P$. chrysosporium.

\begin{tabular}{|c|c|c|c|c|c|c|c|}
\hline \multirow{3}{*}{ Fungos } & $\mathrm{Ab}$ & 6 & m & ic & - & $\mathrm{nm}^{*}$ & \multirow{3}{*}{$\begin{array}{c}\text { X final } \\
\text { de } \\
\text { degradação }\end{array}$} \\
\hline & \multicolumn{6}{|c|}{ Dias } & \\
\hline & 0 & 2 & 4 & 6 & 8 & 10 & \\
\hline
\end{tabular}

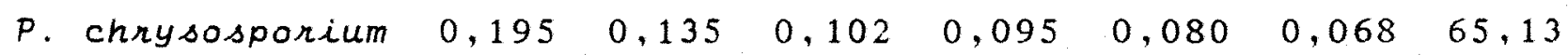

Botryosphaeria $\quad 0,187 \quad 0,185 \quad 0,173 \quad 0,150 \quad 0,138 \quad 0,121 \quad 35,19$

Fusarium $\quad 0,200 \quad 0,183 \quad 0,135 \quad 0,112 \quad 0,098 \quad 0,075 \quad 62,50$

Sponotrichum $\quad 0,188 \quad 0,180 \quad 0,173 \quad 0,170 \quad 0,156 \quad 0,120 \quad 36,17$

Basidiomiceto (1) $0,196 \quad 0,150 \quad 0,124 \quad 0,109 \quad 0,087 \quad 0,080 \quad 50,00$

Basidiomiceto (2) $0,200 \quad 0,195 \quad 0,168 \quad 0,127 \quad 0,107 \quad 0,073 \quad 63,50$

Basidiomiceto (3) $0,183 \quad 0,170 \quad 0,147 \quad 0,122 \quad 0,101 \quad 0,075 \quad 59,02$

* Os dados apresentados constituem a média de duas repetições. 


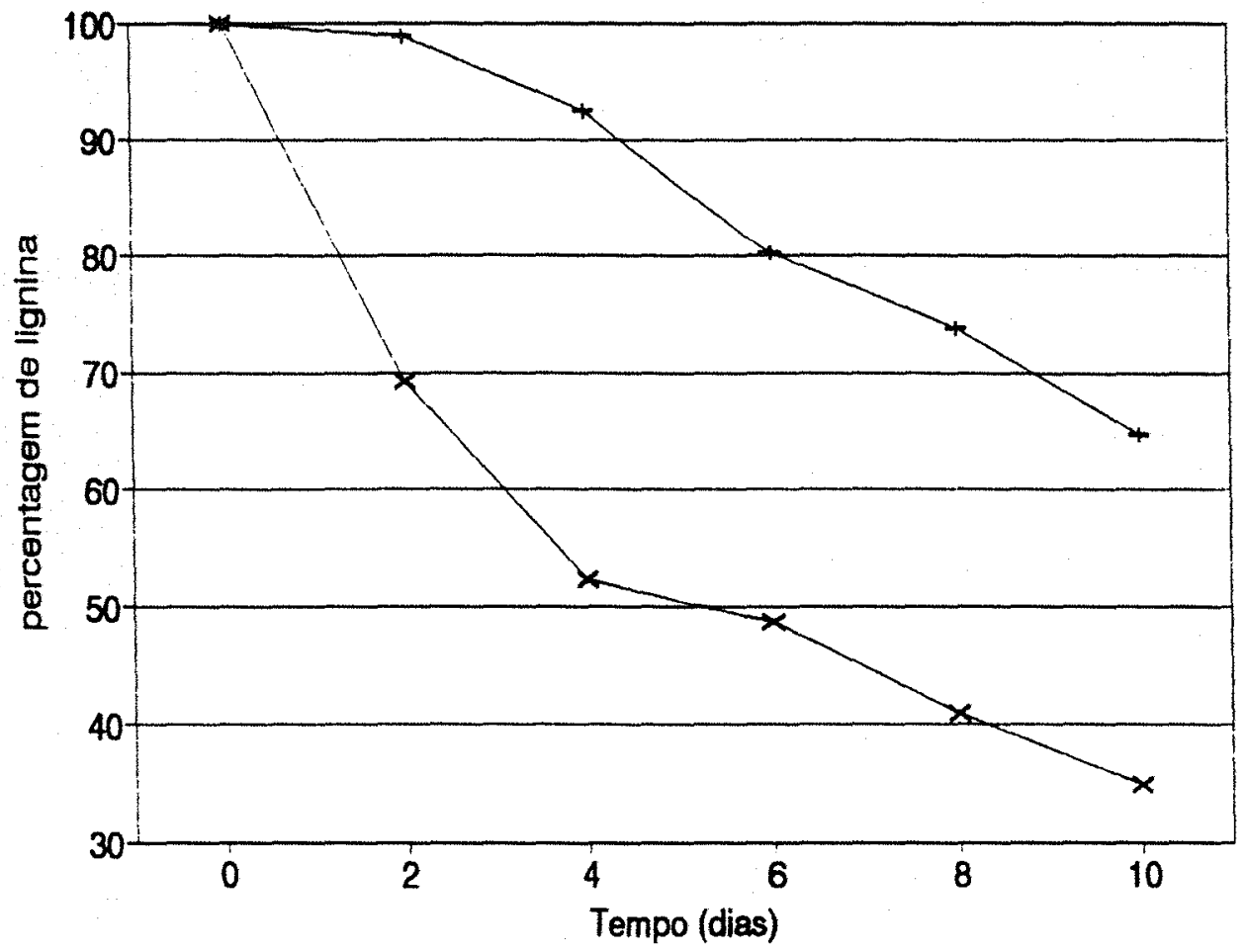

(x) P. chrysosporium

(+) Botryosphaeria

Figura 4. Atividade lignolitica do fungo Botryosphaeria de cavacos com podridão branca, comparado com o fungo $P$. chrysosporium.

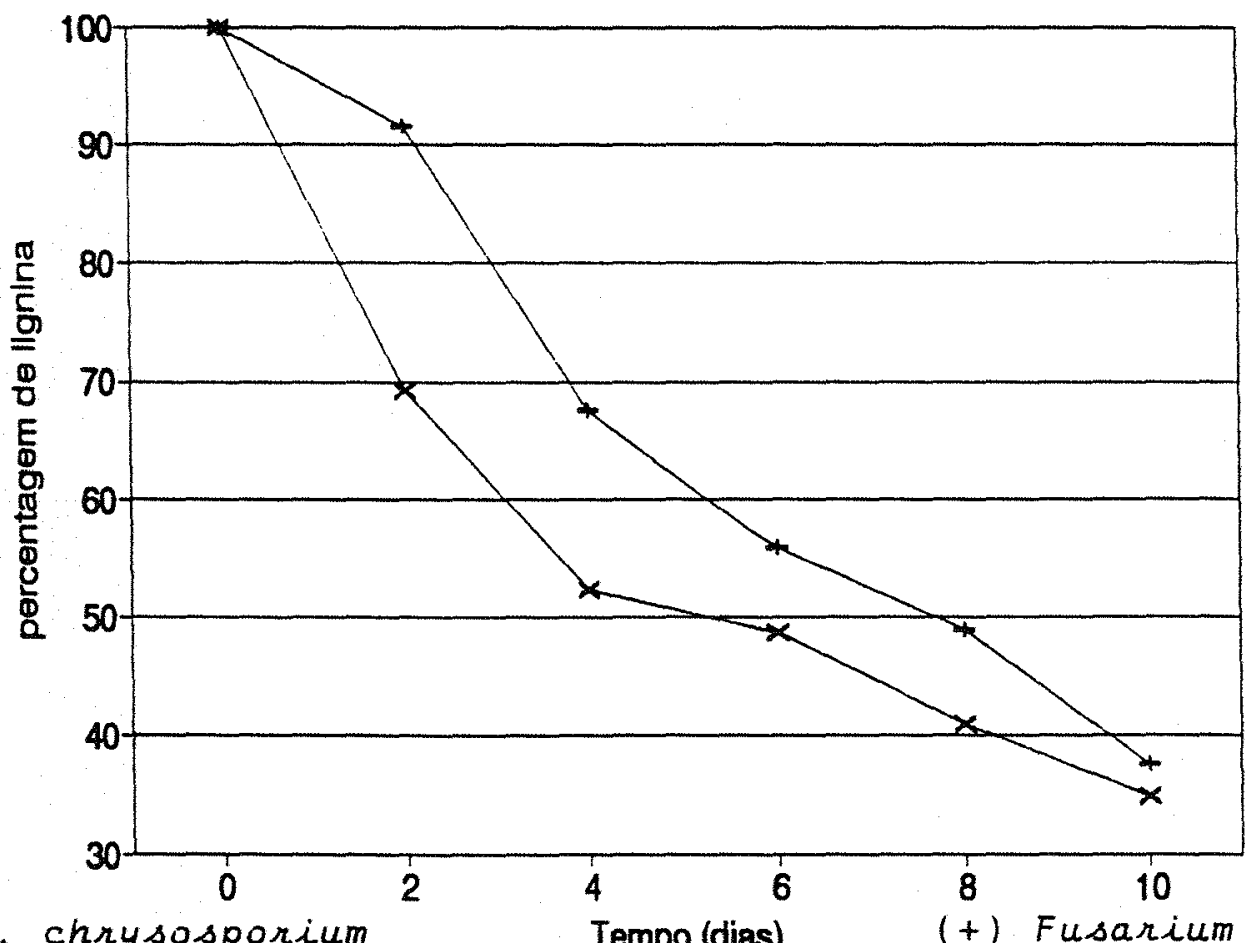

(x) P. chrysosporium Tempo(dias) (t) Fusarium

Figura 5. Atividade lignolitica do fungo Fusarium de cavacos com podridão branca, comparado com o fungo $P$. chrysosporium. 


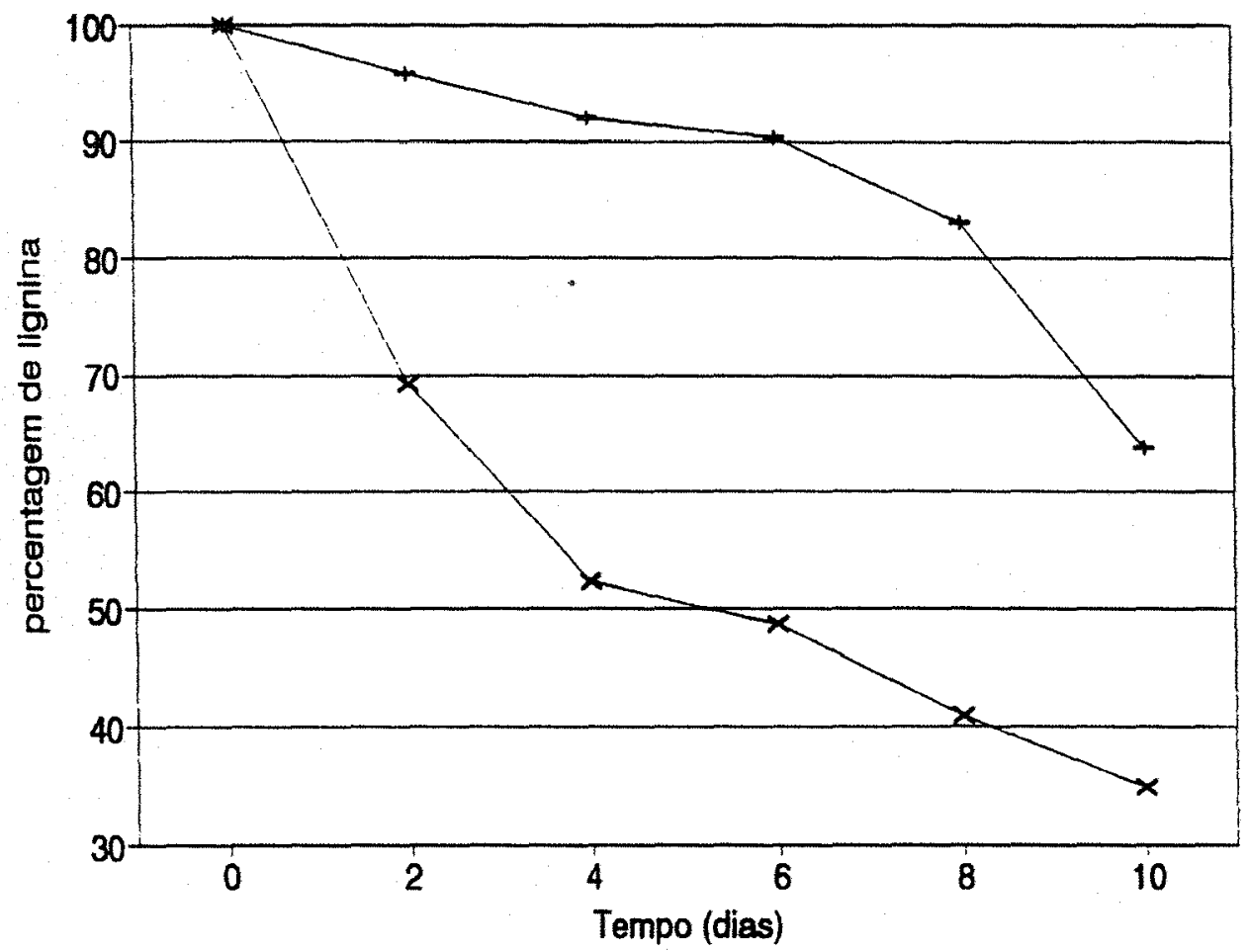

(x) P. chrysosporium

$(+)$ Sponotrichum

Figura 6. Atividade lignolítica do fungo sponotrichum de cavacos com podridão branca, comparado com 0 fungo $P$. chrysosporium.

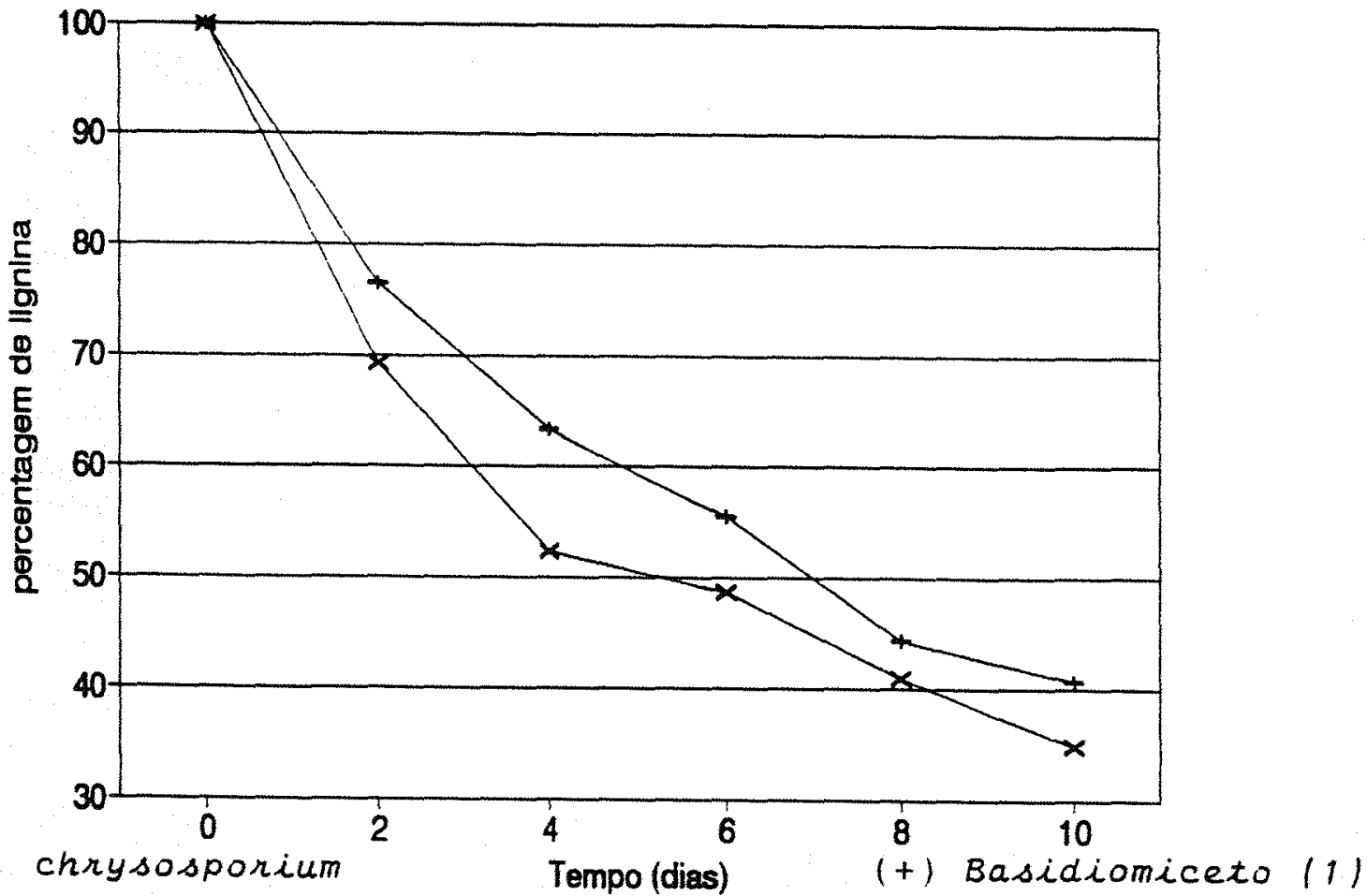

(x) P. chrysosporium Tempo(dias) (+) Basidiomiceto (1)

Figura 7. Atividade lignolítica do fungo Basidiomiceto (1) de cavacos com podridão branca, comparado com $o$ fungo $P$. chrysosporium. 
64 .

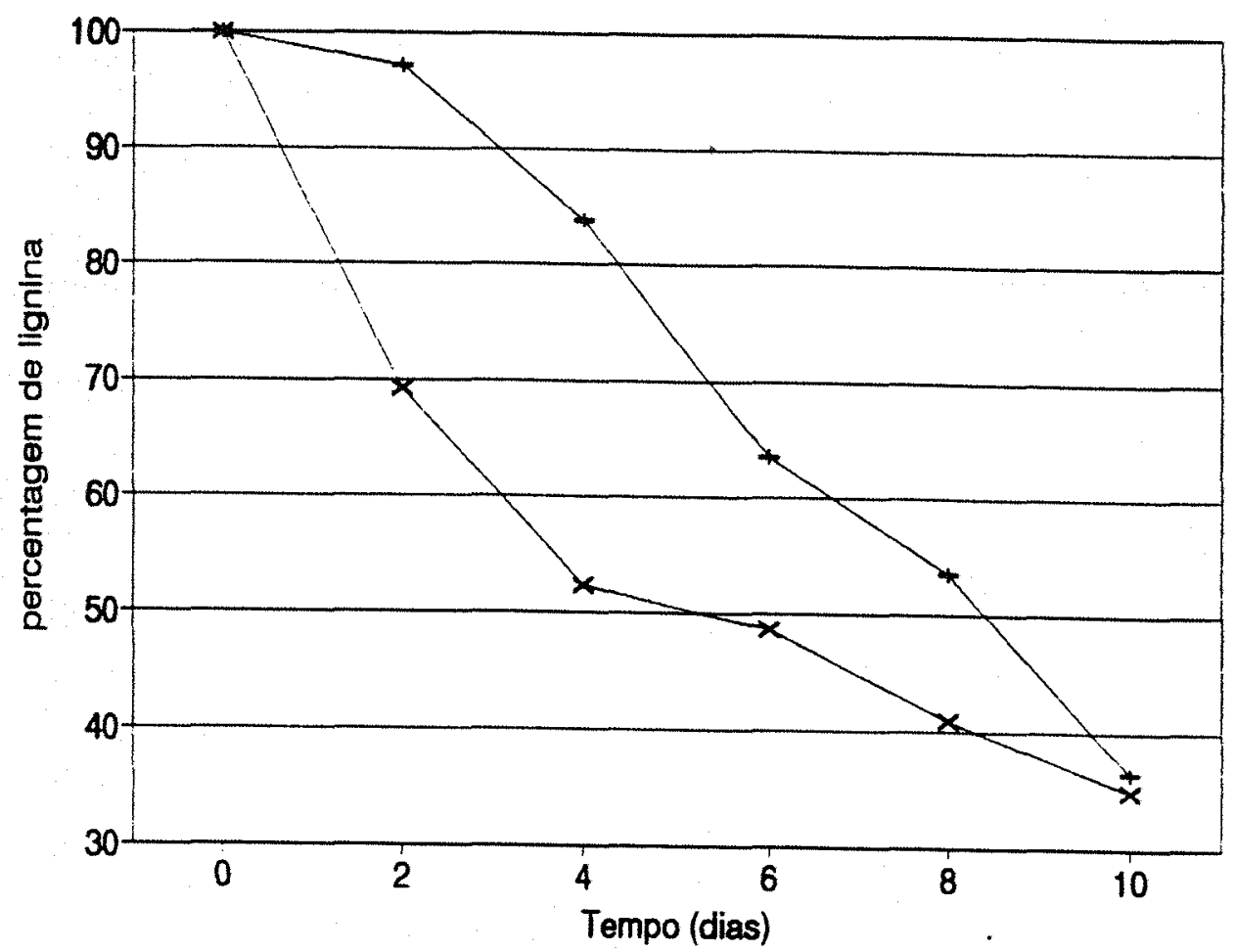

(x) P. chrysosponium

(+) Basidiomiceto (2)

Figura 8. Atividade lignolitica do fungo Basidiomiceto (2) de cavacos com podridão branca, comparado com o fungo $P$. chrysasporium.

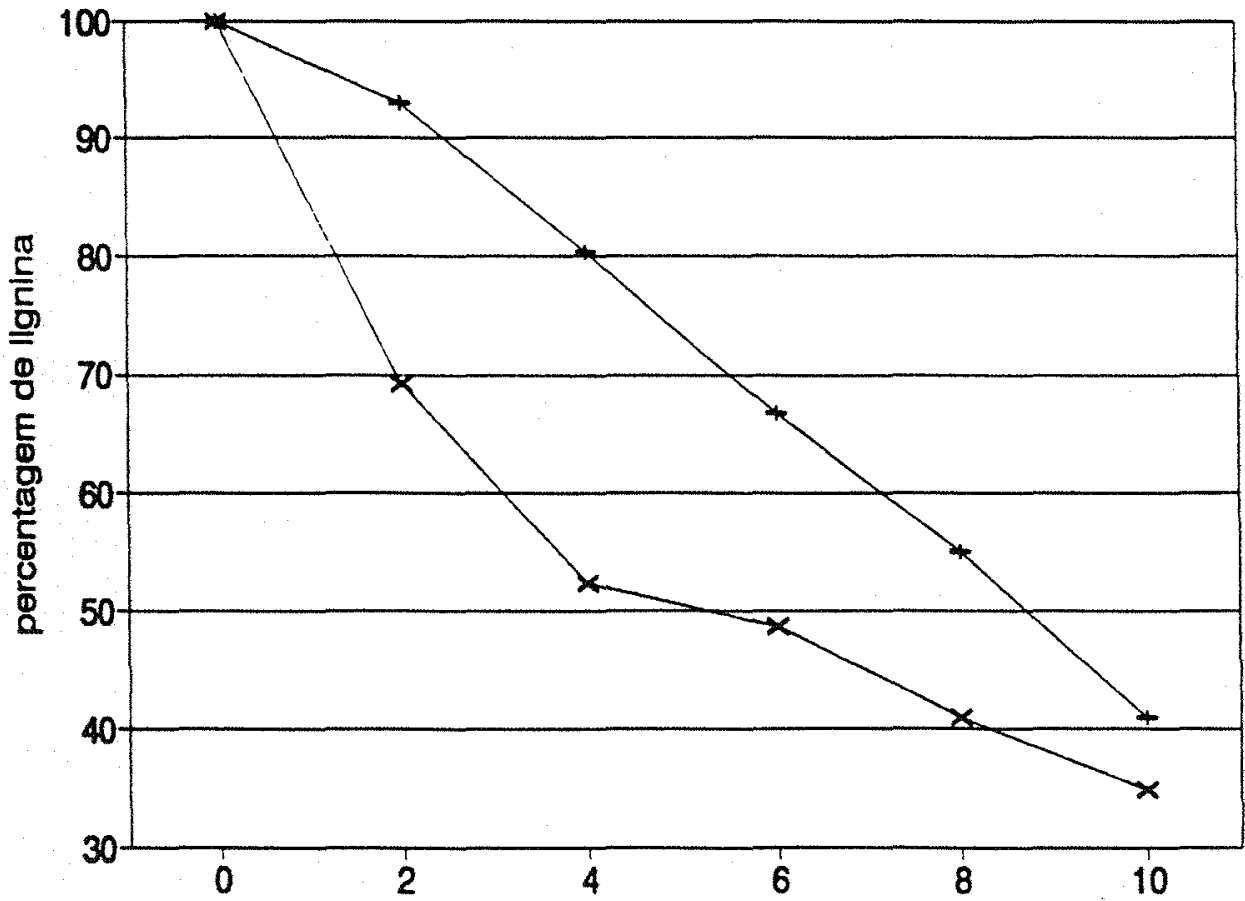

(x) P. chrysosporium Tempo(dias) (t) Basidiomiceto (3)

Figura 9. Atividade lignolitica do fungo Basidiomiceto (3) de cavacos com podridão branca, comparado com o fungo $P$. chrysosporium. 
Com relação a atividade lignolítica dos fungos isolados, não foi encontrado nenhum fungo com atividade superior ao $P$. chrysosporium. No entanto quatro fungos apresentaram atividade de degradação próxima ao do $P$. chrysosporium. CARRAU et alii (1987) relataram $60 \%$ de degradação, quando o substrato utilizado foi lignina extraída de bagaço de cana-de-açúcar, com o fungo $P$. chrysosporium. Em experimento similar, VICENTE (1989) detectou $58 \%$ de degradação no mesmo substrato, para o mesmo período de incubação. Segundo este último autor, o fungo Fusarium solani foi considerado o melhor entre os isolados degradando $53 \%$ do substrato.

\subsection{Pré-Tratamento Biológico dos Cavacos}

4.7.1. Teste de Eficiência de Inoculação

Este teste de eficiência foi efetuada pela inoculação dos cavacos com $100 \mathrm{ml}$ de meio vermiculita com micélio através do reisolamento dos fungos selecionados aos 30 e 60 dias de incubação. No reisolamento foram obtidas colônias puras de fungo sendo, os resultados apresentados na Tabela 23 . 
Tabela 23. Reisolamento dos fungos a partir dos cavacos inoculados.

\begin{tabular}{|c|c|c|c|}
\hline \multirow{2}{*}{ Tratamento } & \multirow{2}{*}{ Frasco } & \multicolumn{2}{|c|}{ Tempo } \\
\hline & & 30 dias & 60 dias \\
\hline I C & $\begin{array}{l}F_{1} \\
F_{2} \\
F_{3} \\
F_{4} \\
F_{5}\end{array}$ & $\begin{array}{l}+ \\
+ \\
+ \\
+ \\
-\end{array}$ & $\begin{array}{l}+ \\
+ \\
+ \\
+ \\
+\end{array}$ \\
\hline Is 1 & $\begin{array}{l}F_{1} \\
F_{2} \\
F_{3} \\
F_{4} \\
F_{5}\end{array}$ & $\begin{array}{l}+ \\
+ \\
+ \\
+ \\
+\end{array}$ & $\begin{array}{l}+ \\
+ \\
+ \\
+ \\
+\end{array}$ \\
\hline Is 2 & $\begin{array}{l}F_{1} \\
F_{2} \\
F_{3} \\
F_{4} \\
F_{5}\end{array}$ & $\begin{array}{l}+ \\
+ \\
+ \\
+ \\
+\end{array}$ & $\begin{array}{l}+ \\
+ \\
+ \\
+ \\
+\end{array}$ \\
\hline I s 3 & $\begin{array}{l}F_{1} \\
F_{2} \\
F_{3} \\
F_{4} \\
F_{5}\end{array}$ & $\begin{array}{l}+ \\
+ \\
+ \\
+ \\
+\end{array}$ & $\begin{array}{l}+ \\
+ \\
+ \\
+ \\
+\end{array}$ \\
\hline Is 4 & $\begin{array}{l}F_{1} \\
F_{2} \\
F_{3} \\
F_{4} \\
F_{5}\end{array}$ & $\begin{array}{l}+ \\
+ \\
+ \\
+ \\
+\end{array}$ & $\begin{array}{l}+ \\
+ \\
+ \\
+ \\
+\end{array}$ \\
\hline
\end{tabular}

$+=$ Presença do fungo

- = Ausência do fungo

Ic = Phanerochaete; Is 1 = Fusarium; Is $2=$ basidiomiceto(1);

Is3 = Basidiomiceto(2); Is4 = Basidiomiceto(3).

A recuperação do fungo, a partir dos cavacos inoculados com meio de cultura, indicou que houve colonização da madeira, demonstrando que o método de inoculação foi eficiente.

Os cavacos de E. grandis colonizados pelos fungos selecionados, foram utilizados para a determinação da densidade 
básica, determinação da composição química e obtenção da celulose não branqueada.

\subsubsection{Densidade Básica}

Os resultados obtidos para densidade básica da madeira, com amostragem sobre os cavacos são apresentados na Tabela 24.

Tabela 24. Densidade básica de cavacos de madeira de Eucalyptus grandis após vários tratamentos.

\begin{tabular}{c|c}
\hline Tratamento & Densidade Básica $\left(\mathrm{g} / \mathrm{cm}^{3}\right)$ \\
\hline Testemunha (T) & 0,502 \\
Testemunha (Ta) & 0,485 \\
Ic & 0,462 \\
Is1 & 0,470 \\
Is2 & 0,458 \\
Iss & 0,453 \\
Is4 & 0,474 \\
Ist & 0,468 \\
\hline
\end{tabular}

* Média de duas repetições.

\subsection{Análises Químicas}

Os resultados encontrados para a composição química quantitativa dos cavacos são mostrados na Tabela 25. 
Tabela 25. Composição química $(\%)$ dos cavacos de madeira de Eucalyptus grandis após vários tratamentos.

\begin{tabular}{l|c|c|c}
\hline \multirow{2}{*}{ Tratamentos* } & \multicolumn{3}{|c}{ Componentes da madeira } \\
\cline { 2 - 4 } & Holocelulose & Lignina & Extrativos Totais \\
\hline T & 70,05 & 25,07 & 3,55 \\
Ta & 70,12 & 25,10 & 2,73 \\
Ic & 69,22 & 22,14 & 1,28 \\
Is 1 & 69,14 & 22,40 & 1,14 \\
Is 2 & 68,97 & 22,33 & 1,78 \\
Is 3 & 69,05 & 22,45 & 1,93 \\
Is & 69,37 & 22,12 & 1,23 \\
Ist & 68,13 & 22,03 & 1,04 \\
\hline
\end{tabular}

- Média de 3 repetições

4.8.1. Características da Polpa Não Branqueada

Os resultados obtidos com estas características são apresentados na Tabela 26. 
Tabela 26. Rendimento bruto (RB), rendimento (RD), teor de rejeitos (RE), em porcentagens, e número Kappa de celuloses não branqueadas de Eucalyptus grandis.

\begin{tabular}{|c|c|c|c|}
\hline $\begin{array}{l}\text { Tratamentos } \\
\text { dos cavacos }\end{array}$ & $\begin{array}{l}\text { Parâmetro } \\
\text { analisado }\end{array}$ & $\begin{array}{c}\text { Valores } \\
(\%)\end{array}$ & $\begin{array}{r}\text { Número } \\
\text { Kappa }\end{array}$ \\
\hline Testemunha & $\begin{array}{l}R B \\
R D \\
R E\end{array}$ & $\begin{array}{r}48,30 \\
41,88 \\
6,42\end{array}$ & 25,1 \\
\hline Autoclavados & $\begin{array}{l}R B \\
R D \\
R E\end{array}$ & $\begin{array}{r}48,77 \\
42,79 \\
5,98\end{array}$ & 23,2 \\
\hline I c & $\begin{array}{l}R B \\
R D \\
R E\end{array}$ & $\begin{array}{r}50,05 \\
49,84 \\
0,21\end{array}$ & 19,8 \\
\hline$I_{1}$ & $\begin{array}{l}R B \\
R D \\
R E\end{array}$ & $\begin{array}{r}50,16 \\
49,81 \\
0,35\end{array}$ & 20,0 \\
\hline I s 2 & $\begin{array}{l}\mathrm{RB} \\
\mathrm{RD} \\
\mathrm{RE}\end{array}$ & $\begin{array}{r}50,13 \\
49,89 \\
0,24\end{array}$ & 19,7 \\
\hline Is 3 & $\begin{array}{l}\text { RB } \\
\text { RD } \\
\text { RE }\end{array}$ & $\begin{array}{r}49,98 \\
49,24 \\
0,74\end{array}$ & 20,2 \\
\hline $\mathrm{IS}_{4}$ & $\begin{array}{l}\mathrm{RB} \\
\mathrm{RD} \\
\mathrm{RE}\end{array}$ & $\begin{array}{r}50,12 \\
49,17 \\
0,95\end{array}$ & 21,0 \\
\hline I ST & $\begin{array}{l}\mathrm{RB} \\
\mathrm{RD} \\
\mathrm{RE}\end{array}$ & $\begin{array}{r}50,90 \\
50,07 \\
0,83\end{array}$ & 20,5 \\
\hline
\end{tabular}

* Média de três repetições

Analisando-se os resultados da Tabela 24, pode-se observar uma redução na densidade básica dos cavacos tratados biologicamente pelos fungos. Esta diminuição da densidade foi acompanhada, por alterações na composição química quantitativa dos cavacos (Tabela 25). Portanto, a redução na densidade básica observada pode indicar uma hidrólise parcial dos componentes da ma- 
deira que foi detectada pelas análises quantitativas efetuadas. Concomitantemente ao decréscimo da densidade básica, observou-se um aumento no rendimento depurado. ORIARAN et alii (1990) trabalhando com o fungo $P$. chrysosporium em madeira de $P$. tremuloides, também verificaram aumento de rendimento. Os autores propuseram que o incremento do rendimento deve-se parcialmente à maior facilidade de penetração do licor de cozimento, o que facilita a remoção dos componentes da madeira do interior dos vasos e das pontuações e permite a maior difusão do licor. A melhor penetração do licor aumenta a eficiência do processo, resultando em menor demanda de reagentes químicos para níveis comparáveis de número Kappa. Isso explica uma percentagem maior de rejeitos em cavacos não tratados biologicamente (Tabela 26).

A celulose de cavacos não tratados com os fungos apresentou maior número Kappa, quando comparada com a celulose de cavacos tratados biologicamente, o que confirma os resultados da análise química dos respectivos cavacos, que indicam maior teor de lignina para os cavacos testemunha. Portanto, a carga alcalina utilizada não foi suficiente para deslignificação dos cavacos, resultando no incremento do teor de rejeitos.

De maneira geral, os resultados da polpação dos cavacos tratados com os isolados separados ou juntos (Tabela 26) apresentaram as mesmas tendências, dos cavacos tratados biologicamente com P. chrysosporium. 


\section{CONCLUSÃO}

Nas condições do presente trabalho, foi possível chegar às seguintes conclusões:

1. Os fungos isolados, a partir de cavacos retirados da pilha foram identificados como Aspergillus sp., Penicillium sp., Sporotrichum sp., Rhizomucor sp., Botryosphaeria sp., Fusarium sp., Trichoderma sp., Eurotium sp. e mais três fungos distintos não identificados da classe dos Basidiomicetos.

2. No decorter do período de armazenamento houve variação significativas nos teores de extrativos, holocelulose e lignina da madeira.

3. Houve queda gradual nos teores de holocelulose e lignina, iniciada a partir do momento em que os cavacos foram colonizados pelos fungos Botryosphaenia sp., Fusarium sp., Trichoderma sp., Eurotium sp., e os três basidiomicetos.

4. Visando o acompanhamento da distribuição dos fungos observouse que o $\mathrm{pH}$ não pode ser considerado um parâmetro adequado. 
5. A atividade lignolítica produzida pelos fungos Fusarium sp. e nos Basidiomiceto no3 selecionados foi similar a de Phanerochaete chrysosporium.

6. O pré-tratamento biológico da madeira, em todos os casos, resultou na redução do teor de lignina acompanhada pelo aumento do rendimento bruto, diminuição dos rejeitos e conseqüentemente, aumento do rendimento depurado.

7. Os fungos selecionados apresentaram-se eficientes, com potencial para redução de reagentes químicos no processo kraft. 


\section{B I BL I OGRAF I A}

ABTCP, Associação Técnica Brasileira de Celulose e Papel - Divisão de Normas e Especificações. São Paulo, 1989.

ADAMS, P. R. \& DEPLOEY, J. J. Enzyme produced by thermophilic fungi. Mycologia, New York, 1978. 70:906-910.

AKHTAR, M.; ATTRIDGE, M.; MYERS, G.; KIRK, T. K. ; BLANCHETTE, R. Biomechanical pulping of Loblolly pine with different strains of the white-rot fungus Ceriporiopsis subvermispora. Tappi Journal, At lanta, 1992.75(2):105-9.

ALMEIDA, M. L. O. Celulose e papel: tecnologia de fabricação da pasta celulosica. 2.ed. São Paulo. SENAI, 1988. V.1.405p.

ANDER, P. \& ERIKSSON, K. E. Selective degradation of wood components by white rot fungi. Physiologia Plantarium, Copenhagen, 1977. 41:239-248.

ANTUNES, L. A. F.; CEREDA, M. P. \& CAMARGO, R. Decomposição simulada da palha de arroz e obtenção de microrganismos celuloliticos. Arquivos de Biologia e Tecnologia, Curitiba, 1986. 29(3):533-43.

APINIS, A. E. Dactylomyces and Thermoascus. Transactions of the British Mycological Society. London, 1967. 50:573-82.

AUER, C. G. Levantamento de fungos termófilos associados a pilhas de cavacos de Eucalyptus spp. Piracicaba, 1986, 99p. (Dissertação de Mestrado).

AUER, C. G.; FERRARI, M. P. \& BARRICHELO, L. E. G. Utilização do fungo termófilo Thermoacus aunantiacus na degradação d irigida de cavacos de eucalipto. Silvicultura, São Paulo, 1986. 11(41): 194 .

BARRICHELO, L. E. G. \& AUER, C. G. Programa de biotecnologia em celulose e pape1. CEBETC/FEALQ, Piracicaba, 1986.

BEETS, W. B. \& DART, R. K. The degradation of lignin related compounds by Aspergillus blavus. Journal of General Microbiology, London, 1988. 134:2413-20. 
BJORKMAN, E. \& HAEGER. Outdoor storage of chips and demage by microrganisms. TAPPI, At lanta, 1963. 46:129-133.

BOIS, P. J.; FLICK, R. A. \& GILMER, W. D. A study of outside storage of hard wood pulp chips in the southeast. TAPPI, At lanta, 1962.45:609-618.

BROWNING, B. L. The chemistry of wood. Interscience publishers, 1963. $689 \mathrm{p}$.

CARRAU, F. M.; NEIROTTI, E. ; GAGGERO, C. \& AZEVEDO, J. L. Separation and biodegradation of $r$ ice hulls and sugarcane bagasse alkali lignins. Arquivos de Biologia e Tecnologia, Curitiba, 1987, 30:577-84.

CASEY, J, P. Pulp and paper chemistry and chemical. Willey Interscience, New York, 1980. V.1.

COONEY, D. G. \& EMERSON, R. Thermophilic fungi. San Francisco W. H. Freeman and Company, 1964. 183p.

COWL ING, E. B.; HARLEY, W. L. \& WEINER, J. Changes in value and utility of pulpwood during harvesting, transport and storage. TAPPI, At lanta, 1978. V.57, 12:120-3.

CRAWFORD, D. L. \& CRAWFORD, R. L. Micrbial degradation of lignin. Enzyme and Microbial Technology. Guildford, 1980. $2: 11-27$.

CRAWFORD, R. L. \& CRAWFORD, D. L. Recent advances in studies of the mechanisms of microbial degradation of lignins. Enzyme and Microbial Technology, Guildford, 1984.6:434-42.

DICKINSON, C. H. Decomposition of litter in soil, London, Academic Press, 1974.

DIEHM, R. A. Microbiologia de la pulpa e del papel. In: LIBBY, C. E. Ciência y tecnologia de la pulpa e del papel. Editora Contineltal, México, 1977. p.437-61. V.2.

DROZDOWICZ, A. G. Microbiologia do solo. In: ROITMAN, I.; TRAVASSOS, L. R. \& AZEVEDO, J. L. Tratado de microbiologia. 1ed. São Paulo, Mande, 1991. V.2.186p.

EMERSON, R. Thermophiles. In: AINSWORTIH, G. C. \& SUSSMAN, Coord. The fungi - An Advanced Treatise, v. III. New York, Academic Press. 1968. p.105-128.

FAISON, B. D.; KIRK, T. K. \& FARREL. R. L. Role of veratril alcohol in regulating ligninase activity in Phanerochaete chrysosporium. Applied and Environmental Microbiology, Baltimore, 1986. 52:251-254.

FENGEL, D. \& WEGENER. Wood chemistry, ultrastructure, reactions. Walter de Gruyter, New York, 1984.

FLANNIGAN, B. \& SELLARS, P. N. Activities of thermophilous fungi from barley kernels against arabinoxylan and carboxymetilcellulose. Transactions of the British Mycological Society, London, $58(2): 338-341$, April 1972 . 
FOELKEL, C. E. B.; BARRICHELO, L. E. G. \& MILANEZ, A. F. Estudo comparativo das madeiras de $E$. saligna, $E$. paniculata, $E$. maculata e E. teneticonnis para produção de celulose sulfato. IPEF, Piracicaba, 1975. (10):17-37.

FUNAGUMA, T.; TSUJI, H. \& HARA, A. Purification and some properties of celulose $1,4-\beta-c e l l o b i o s i d a s e$ from a straim of Penicillium sp. Journal Fermentation Technology, Osaka, 1986. 64(1):77-80.

GARCIA, S. \& LATGE, J. P. A new colorimetric method for dosage of lignin. Biotechnology Techniques, France, 1987. V.1. no 1 , $63-68$.

HALKETT, W. F.; CONNORS, W. J.; KIRK, T. K. \& ZEIKUS, J. G. Microbial decomposition of synthetic C labeled lignins in a variety of natural material. Applied and Environmental Microbiology, Balt imore, 1977. 33:43-51.

HATAKKA, A. \& TERVILÃ-WILO, A. Ligninases of white-rot In: Soviet fennish seminar on microbial degradation of ignocellulosic raw material. Proceedings, Thilisk, 1985 . p. $65-75$.

HATTON, J. V. Precise studies on the effect of outside chip storage on fiber yield: white spruce and lodgepole pine. TAPPI, At lanta, 1970.53:627-638.

HIGHLEY, T. L. Hemicellulases of white and brown rot fungi in relation host preferences. Material und Organismen, Berlin, 1976. 11:33-46.

JANSHEKAR, H.; BROWN, C. \& FIECHTER, A. Determination of biodegraded lignin by ultraviolet spectophotometry. Analytica Chymica Acta, Amsterdam, 1981. 130:81-91.

JEFFRIES, T. W. ; CHOI, S. \& KIRK, T. K. Nutritional regulation of lignin degradation by Phanerochaete chrysosporium. Applied and Environmental Microbiology, Baltimore, 1981 . $42: 290-6$.

KAARIK, A. Sapwood staining fungi. The international research group on wood preservation. Buckghamshire, 1974.65p.

KAARIK, A. Decomposition of wood. In: DICKINSON, C. H. \& PUGH, G. J. F., Biology of plant litter decomposition, Academic Press, London, 1975. V.1, p.129-174.

KIRK, T. K. Effects of microrganisms on lignin. Annual Review of Phytopathology. Palo Alto, 1971.9:185-210.

KIRK, T. K. Toward elucidating the mechanism of the system in basidiomycetes. In: Trends in the biology of fermentations, Plenum Press, New York, 1981. p.131-149.

KIRK, T. K. Degradation and conversion of lignocelluloses. In: SMITH, J. E. et alii. The filamentous fungi. Fungal Technology, London, Edward Arnold, 1983. V.4. p.266-295. 
KIRK, T. K. Biochemistry of 1 ignin degradation by Phanerochaete chrysosporium. Biochemistry and genetics of cellulose degradation, Academic Press, San Diego, 1988. p.315-332.

KIRK, T. K. \& CHANG, H. M. Decomposition of lignin by white rot fungi II. Characterization of herrilydegraded lignin from decayed spruce. Holzforchung, Berlin, 1975.29:56-64.

KIRK, T. K. ; CONNORS, W. J. \& ZEIKUS, J. G. Requeriment for a growth substrate during lignin decomposition by two wood rotting fungi. Applied and environmental microbiology, Baltimore, 1976 . 32:192-94.

KIRK, T. K.; JEFFRIES \& LEATHAM. G. F. Biotechnology applications and implications for the pulp and paper industry. TAPPI Journal, 1983. 66:45-41.

KIRK, T. K. \& HIGHLEY, T. L. Quantitative changes in structural components of conifer wood during decay by white and brown rot fungi. Phytopathology, 1973. 63:1338-42.

KIRK, T. K. ; SHULTZ, E . ; CONNORS, W. J . ; LORENZ, L . F . ; BEIKUS . J. G. Influence of culture parameters on lignin metabolism by $P$. chrysosporium. Archives of microbiology, Berlin, 1978 . $117: 277-285$.

LEISOLA, M. S. A. ; KOZUL IC, B.; MEUSSODEFFER, F. \& FIECHTER, A. Homology amoung multiple extracellular peroxidases by $P$. chrysosporium. Journal of Biological Chemistry, Baltimore, 1987. 262:419-424.

LEI SOLA, M. S. A.; ULMER, D. \& FIECHTER, A. Problem of oxigem transfer during degradation of lignin by $P$. chrsosporium. European Journal of Applied Microbiology and Biotechnology, Berlin, 1983. 17:113-16.

LEISOLA, M. S. A.; ULMER, D. C.; WALDNER, R. \& FIECHTER, A. Role of veratryl alcohol in degradation by $P$. chrysosporium. Journal of Biotechnology, Amsterdam, 1984, 1:331-39.

LEPAGE, E. S. coord. Manual de preservação de madeira, IPT DIMAD, $1986 . \mathrm{V} .1,342 \mathrm{p}$.

LEVY, J . F \& \& DICKINSON, D. J . Wood In: ROSE, A. H. ed Microbial biodegradation, London, Academic Press, 1981 . p. $19-60$.

LIMA, A. F.; RODES, L. \& PHILIPP, P. Introdução. In: D'ALMEIDA, M. L. O. (ed). Celulose e pape 1: tecnologia de fabricação da pasta celulósica. 2.ed. São Paulo, SENAI, 1988. V.1. $405 \mathrm{p}$.

MANDELS, M. \& REESE, E. T. Induction of cellulase in Trichoderma viride as influenced by carbon sources and metals. Journal of Bacteriology, Baltmore, 1960. 73:269-78. 
MALTSEVA, O. V.; MYASOEDOWA, N. M.; LEONTIEVSKY, A. A. \& GOIOVLEVA, L. A. Characteristics of the ligninolytic system of Panus trigrinus. In: Soviet Fennish Seminar on Microbial Degradation of Lignocellulosic Raw Materiales: s.n.t. Proceedings, Thilisk, 1986, p.74-82.

OBERT, F. Sul metabolismo di mono-, oligo-, e polissacaridi in Thermoascus aurantiacus Miehe. Allionia. Turin, 1979. 23:7982 .

OKI, T. SHINOMOTO, M. \& ISHIKAWA, H. Enzymatic degradation of guaiacylglycerol-B-guaiacyl ether. Mokuzai Gakkaishi, 1986. $32: 448-56$.

ORIARAN, T.; LABOSKY JR, P.; BLANKENHORN, P. R. Kraft pulp and papermaking properties of Phanerochaete chrysosporium degraded aspen. TAPPI Journal, At lanta, 1990. 73:147-52.

OTJEN, L. \& BLANCHETTE, R. Assessment of 30 white rot basiciomycetes for selective lignin degradation. Holzforshung, Berlin, 1987. 41:343-349.

RAMACHANDRA, M. D. L.; CRAWFORD, D. L. \& POMETTO, A. L . Extracellular enzyme activities during lignocellulose degradation by Streptomyces spp. a comparative study of wild-type and genetically manipulated strains. Applied and Environmental Microbiology, Baltimore, 1987. 53:2754-60.

REESE, E. T.; SIU, R. G. H. ; LEVINSON, H. S. The biological degradation of soluble cellulose derivates and its relationship to the mechanism of cellulose hydrolysis. Journal of Bacteriology, Baltimore, 1950. 59:485-97.

RoUmas, N.E. Produção de celulases e fusão de protoplastos em Humícola sp. Piracicaba, 1988. 168p. (Tese de Doutorado ESALQ/USP).

ROWELL, R. M. Reaction of epoxides with wood. Madison, U.S. Deparament of Agriculture, Forest Service, Forest Products Laboratory, 1984. (Research paper FPL 451).

SARKANEN, N. K. \& LUDWIG, C. H. Lignins: occurrence formation, structure and reactions. New York, Willey Interscience, 1971. p.95-195.

SCHEFFER, T. C. Microbiological degradation and the causal organisms. In: NICHOLAS, D. D., ed. Wood deterioration and the prevention by preservative treatments, syracuse University Press, 1973. V.1. p.31-106.

SCHIPPER, M. A. A. On the genere Rhizomucor and Parasitella. Studies in Mycology, Baarn, 1978. 17:53-71.

SETLIFF, E. C. ; MARTON, S. G. ; GRANZOW, S. G. ; ERIKSSON, K. E. Biomechanical pulping with white-rot fungi. TAPPI Journal, At lanta, 1990.73(8):141-7.

SIMÕES, J. W. ; COELHO, A. S. R. ; MELLO, H. A. \& COUTO, H. T. Z . Crescimento e produção de madeira de eucalipto. IPEF, Piracicaba, 1980. 20:77-97. 
SJÖSTRÖM, E. Wood chemistry. Fundamentals and applications. New York, Academic Press, 1981. 223p.

SREBOTNICK, E. ; MESSENER, K. \& FOISNER, R. Penetrability of white rot degraded Pine wood by the lignin peroxidase of $P$. chrysosporium. Applied and environmental microbiology, Baltimore, 1988, 54:2608-14.

SMITH, D. M. Maximum moisture content method for determining specific gravity of small wood samples. Madison, U.S. Forest Laboratory (Report number 2014), 1954, 8p.

SMITH, R. S. \& OFOSU-ASIEDU, A. Distribution of thermophilic and thermotolerant fungi in a spruce-pine chip pile. Canadian Journal of Forest Research, Ottawa, 1972 . 2:16-26.

TAN, L. U. L. Purification and characterization of a thermophilic fungus Thermoacus aurantiacus. Canadian Journal Microbial, Ottawa, 1987, 33:689-692.

TANSEY, M. R. Isolation of thermophilic fungi from self-heated industrial wood chip piles. Mycologia, New York, 1971 . $63: 537-47$.

TAPPI. Test methods. Fibrous materials and pulp test. At lanta, 1989. vol. I.

VICENTE, V. A. Isolamento e seleção de fungos lignocelulíticos. Piracicaba, 1989.173p. (Mestrado-ESALQ/USP).

WOOD, T. M. Properties of cellulolytic enzyme systems. In: GOUGHLAM, M. P. (ed.) Cellulose production, properties and applications meeting. Galway, Society Hast Colloquium, 1985. $611 \mathrm{p}$.

ZOCH, L. L. ; SPRINGER, E, L . \& HANJNY, G. J . Storage of aspen whole tree chips under laboratory conditions. USDA Florest Service. FPL Research Paper, Madison, 1976.6p. 